UNIVERSIDADE DE SÃO PAULO

FACULDADE DE FILOSOFIA, LETRAS E CIÊNCIAS HUMANAS

DEPARTAMENTO DE LETRAS MODERNAS

PROGRAMA DE PÓS-GRADUAÇÃO EM LETRAS

LÍNGUA ESPANHOLA E LITERATURAS ESPANHOLA E HISPANO-

AMERICANA

\title{
UMA ANÁLISE DO VERBO TENER À LUZ DO CONFRONTO COM O VERBO TER
}

\section{Kaarina Mirani Hämäläinen Lopes}

Dissertação apresentada ao Programa de PósGraduação em Letras do Departamento de Letras Modernas da Faculdade de Filosofia, Letras e Ciências Humanas da Universidade de São Paulo, para a obtenção do título de Mestre em Letras.

Área de concentração: Língua Espanhola e Literaturas Espanhola e Hispano-americana.

Orientadora: Profa. Dra. Mirta Maria Groppi Asplanato de Varalla.

São Paulo 2008 
"Os erros são meus, os acertos são de Deus"

(A. W. Tozer, 1897-1963)

"Melhor é o fim das coisas do que o seu princípio"

(Eclesiastes 7:8) 
Para todos os meus pais, amigos e irmãos. 


\section{AGRADECIMENTOS}

"E tudo que fizerdes, seja em palavra, seja em ação, fazei-o em nome do Senhor Jesus, dando a ele graças a Deus Pai. (...) fazei-o de todo coração, como para o Senhor e não para homens (...). A Cristo, o Senhor, é que estais servindo." Colossenses 3:17, 23-24.

É mais difícil escrever esses agradecimentos do que pensei que seria. Como colocar em palavras tamanha gratidão e sentimento de dever cumprido? Na verdade, não há como inovar e cada palavra aqui expressa minha alegria em ter tido a ajuda dessas pessoas para chegar a esse ponto.

Agradeço à minha orientadora, Mirta Groppi, por sua ajuda em cada passo que essa dissertação dava em direção a seu final. Por ter me ajudado a encontrar uma linha de pesquisa cada vez que as muitas letras me faziam delirar.

Agradeço à minha família. Aos meus pais, por terem me incentivado a estudar sempre, por terem me deixado em São Paulo para poder terminar mais essa etapa, mas acima de tudo por terem entregado toda a minha educação nas mãos do Senhor há mais de 20 anos atrás. Ao meu tio Haroldo por se interessar por minha pesquisa e tentar entender sua relevância dentro de um mundo tão pragmático. Ao meu irmão, Tiago, por me acompanhar durante as madrugadas de estudo, mesmo estando do outro lado do mundo. Muito obrigada pelas orações.

Valéria, Vanessa, Lívia, Priscila, Luana: obrigada por me animar, por orar por mim, por me escutar, por me incentivar (“estudar é um prazer, o mestrado eu hei de vencer), por me servir (Luana, entregando meus textos e trabalhos na USP; Lívia e 
Priscila por não exigir de mim muita ajuda no serviço da casa), por me receber em visitas quase que de surpresa e por passar a madrugada ouvindo todas as minhas dúvidas e crises existenciais.

Hélio e Márcia, muitíssimo obrigada por terem aberto a casa de vocês, por zelarem por mim como filha, por me darem um lar longe de casa, por me darem atenção e, algumas vezes, exortações mais que necessárias. Tio Adelcio e tia Toninha, também agradeço por todo carinho, café, almoços ocasionais, jantas deliciosas e pudins de leite condensado.

Jean, obrigada por dormir na sala todas as vezes que eu precisava usar o escritório. David, obrigada por me fazer rir. Dexter, obrigada por ser uma inspiração.

Obrigada a tantos outros amigos e irmãos que zelaram por mim em suas orações e que me amam sem mesmo eu ser merecedora.

E, por fim, obrigada, Jesus, por ter cuidado de cada mínimo detalhe que citei ou não nesta lista. Obrigada por me ajudar a encerrar mais este capítulo. Tu és o único motivo de minha alegria, tu és minha esperança real, meu Deus, meu Senhor e meu soberano absoluto. 


\section{RESUMO}

Este presente trabalho compara as construções existenciais do português do Brasil com as construções existenciais do espanhol.

A pesquisa se situa no âmbito da Lingüística Histórica, da análise sintática e semântica dos verbos HAVER e TER no espanhol e português atual e arcaico. As construções existenciais ou de tempo composto no español ocorrem de modo distinto das do português, TER no espanhol somente constrói sentenças que expressam relações de posse.

Levando em conta a origem das línguas portuguesa e espanhola e ainda as realizações de TER e HAVER no português e no espanhol arcaico, o objetivo deste trabalho é entender porque no espanhol não podemos formar sentenças existenciais como as do Português:

1. Por causa do feriado, há somente três alunos na sala.

2. Por causa do feriado, têm somente três alunos na sala.

3. Hay dos alumnos en el aula.

4. *Tiene una mujer en la cocina.

No espanhol, o verbo TER somente é usado nas construções possessivas:

5. Yo tengo un gato y una perrita.

Tendo como base princípios da teoria gerativa, busco fazer uma análise das estruturas sintática e semântica desses verbos e suas realizações, a fim de compreender as diferenças e semelhanças que existem nas construções existências no português e no espanhol. 


\begin{abstract}
This present study compares the construction of existential phrases in brazilian Portuguese with the construction of existential phrases in Spanish.

This research is under the Historical Linguistics, syntactical and semantic analysis of verbs HAVER and TER in Spanish and Portuguese current and archaic. The existential phrases or time composed in Spanish occur distinctly from Portuguese, TER in Spanish only builds sentences that express relations of possession.

Taking into account the origin this two languages and even the achievements of TER and HAVER in Portuguese and Spanish archaics, the objective of this work is to understand why in Spanish we can not form existential sentences as those in Portuguese:
\end{abstract}
6. Por causa do feriado, há somente três alunos na sala.
7. Por causa do feriado, têm somente três alunos na sala.
8. Hay dos alumnos en el aula.
9. *Tiene una mujer en la cocina.

In Spanish, TER is only used to build possessive sentences:

10. Yo tengo un gato y una perrita.

Based on principles of the generative theory, I make an analysis of the syntactic and semantics structures of those verbs and their achievements in order to understand the differences and similarities that exist in those constructions in Portuguese and Spanish. 


\section{SUMÁRIO}

\section{CAPÍTULO 1}

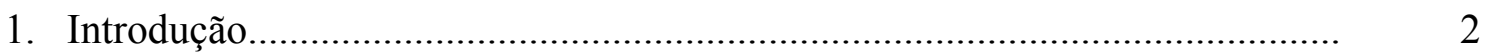

1.1. Justificativa e objetivo..................................................................... 3

\section{CAPÍTULO 2}

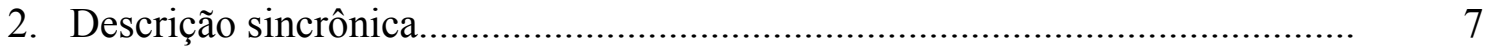

2.1. HABER/TENER nos manuais de gramática do espanhol ........................ 8

2.2. HAVER/TER nos manuais de gramática do português............................ 21

\section{CAPÍTULO 3}

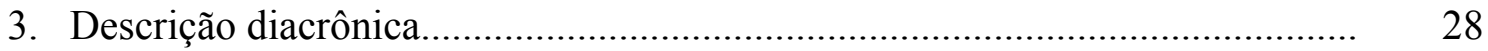

3.1. O português arcaico................................................................................... 29

3.2. O espanhol arcaico............................................................................ 33

3.2.1. O espanhol arcaico segundo o trabalho de Hernández Diaz............ 34

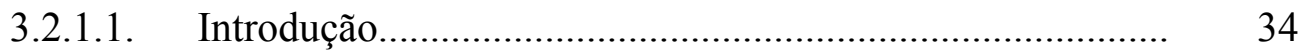

3.2.1.2. A análise de Hernández Diaz............................................. 38

\section{CAPÍTULO 4}

4. Uma proposta para o verbo TER ................................................................... 46

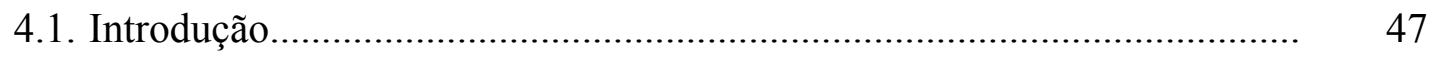

4.2. Idéias sobre as construções impessoais com o verbo TER de Franchi et alii (1998)......

4.3. A teoria do léxico gerativo de Pustejovsky (1998)................................... 54

4.4. A proposta de Viotti (1999).................................................................. 59 
4.5. Uma proposta de análise para os verbos do português arcaico.................. 74

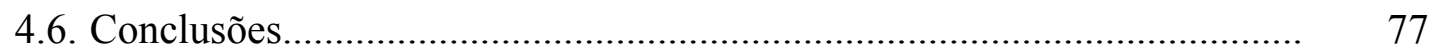

\section{CAPÍTULO 5}

5. Uma análise do verbo TENER à luz do confronto com o verbo TER............... 79

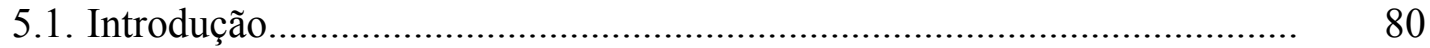

5.2. Teorias, modelos e hipóteses para trabalhar o léxico segundo Mendikoetxea (2004) ............................................................... 84

5.3. A análise de TENER ................................................................................ 90

5.4. Uma proposta de análise para os verbos do espanhol arcaico................... 98

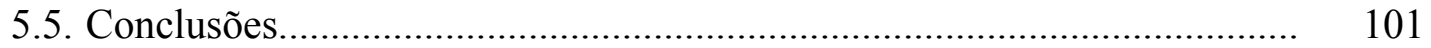

\section{CAPÍTULO 6}

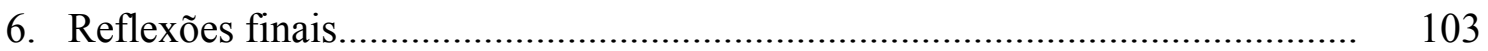

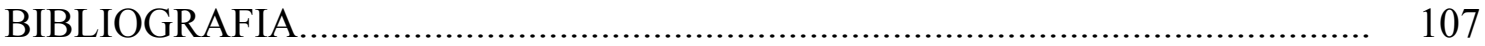


CAPÍTULO 1 


\section{Introdução}

Esta dissertação trata das construções existenciais (CEs) no português do Brasil e no espanhol. Aqui as CEs são as sentenças realizadas no português brasileiro (PB) com os TER e HAVER na sua forma impessoal:

1. Havia uma regra clara sobre como e onde usar esse poder.

2. Tinha uma barata nojenta andando na pia da cozinha.

No caso do espanhol as CEs são feitas com o verbo HABER:

3. Había una persona que sabía de todo lo que se pasaba en la calle.

4. *Tenía una persona que sabía de todo lo que se pasaba en la calle.

Este trabalho se concentra em analisar as diferenças entre as CEs no PB e as CEs no espanhol e analisar a estrutura sintática e semântica das CEs dessas línguas não só atualmente, como também nas suas realizações arcaicas.

Essa comparação se mostra muito interessante porque desde o latim até meados do século XVI, tanto o português quanto o espanhol se comportavam de maneira muito parecida no que diz respeito a esses verbos.

No latim TENERE era usado para indicar algo que se estava segurando nas mãos e HABERE indicava posse de qualquer tipo de objeto, fosse concreto ou abstrato. Com a evolução das línguas românicas, no português arcaico, TEER passou a ser usado primeiramente para indicar posse de bens materiais e, depois, mais genericamente de qualquer tipo de objeto. Já AVER seguiu um caminho interessante e, de pleno indicador 
de posse, passou a ser verbo auxiliar e existencial. A evolução de TEER e de AVER no espanhol arcaico seguiu exatamente o mesmo caminho, ou seja, os mesmos valores eram expressos por esses verbos nas duas línguas.

Entretanto, com o seguimento da gramaticalização desses verbos o português e o espanhol tomaram caminhos diferentes. TER no português manteve seu significado de posse e também passou a ser usado como auxiliar e como existencial. HAVER, por sua vez, continua sendo um verbo impessoal e auxiliar, apesar de ter seu uso quase que restrito à norma culta, sendo pouco usado pelos falantes do PB.

No espanhol, por outro lado, cada verbo seguiu por caminhos bem distintos. TENER é somente usado para relações de posse, deixando HABER com as relações existenciais e com seu uso auxiliar.

\subsection{Justificativa e objetivo}

O objetivo desse trabalho é olhar para as estruturas sintáticas e semânticas de cada uma dessas construções a fim de entender um pouco mais sobre os fatores que levam a essa diferença de interpretação.

A comparação entre duas línguas pode ser uma armadilha. Afinal, línguas diferentes têm estruturas gramaticais diferentes. O que este trabalho tenta fazer é indicar um caminho, lançar uma discussão a respeito de como se formariam essas estruturas dentro do espanhol e, para tanto, vamos nos apoiar em estudos realizados para o português.

Esta dissertação se justifica, pois apesar de haver muitos outros trabalhos sobre as $\mathrm{CE}$, que consideram as duas línguas, a maioria é de cunho descritivo, se limitando a 
apontar as diferenças. Aqui pretendo entender como funcionam as estruturas sintáticas e semânticas dessas estruturas nas duas línguas, tanto no presente, como no passado.

A fim de atingir esses objetivos, no próximo capítulo tratarei da descrição sincrônica de TER/HAVER para o português do Brasil e TENER/HABER para o espanhol. Farei uma breve descrição de como os manuais de gramática trabalham com cada um desses verbos e suas variadas ocorrências.

Em seguida, mostrarei alguns estudos tratam das construções realizadas com esses verbos no português e no espanhol arcaicos. Para a descrição do português arcaico usarei os trabalhos de Rosa Virginia Mattos e Silva. Para a descrição dos dados do espanhol arcaico usarei o trabalho de Rafael Lapesa (1981) e um estudo de Hernández $\operatorname{Diaz}(2006)^{2}$.

No capítulo 4, apresento a proposta de análise de Evani Viotti. Cito também outros autores que contribuíram muito para o entendimento das estruturas sintáticosemânticas das CEs, nomes como Carlos Franchi e Pustejosvsky. Ao tratar das análises de TER e HAVER para o português, procuro estender essas propostas para os dados do português arcaico para também poder esclarecer um pouco como eram as estruturas sintáticas e semânticas desses verbos.

Com os dados das propostas para TER e HAVER do português, no capítulo 5, eu faço uma análise de TENER à luz das propostas de TER, buscando mostrar como se diferenciam em sua estrutura sintática e semântica as CEs do PB e do espanhol não só atualmente, mas também no português e espanhol arcaicos.

Por último, escrevo uma conclusão para tentar mostrar qual é a minha intuição a respeito dos dados e das propostas de cada um dos autores e qual proposta considero mais viável para analisar tanto os dados do português quanto os dados do espanhol.

\footnotetext{
${ }^{1}$ LAPESA, Rafael. História de la lengua española, 1981.

${ }^{2}$ COMPANY, C.C. Sintaxis histórica de la lengua española: primera parte: la frase verbal. V.1, 2006.
} 

CAPÍTULO 2 


\section{Descrição sincrônica}

Neste capítulo, apresento uma descrição sincrônica dos verbos HABER e TENER nos manuais de gramática do espanhol e dos verbos HAVER e TER nos manuais de gramática do português. O objetivo é mostrar o que dizem os gramáticos a respeito de cada um desses verbos e, posteriormente, avaliar como isso pode ajudar na análise das construções existenciais.

Para os dados do espanhol usei os manuais da Real Academia Española (1973) ${ }^{3}$, o manual de Gili y Gaya (1961) ${ }^{4}$, o manual de Alarcos e a "Gramática descriptiva de la lengua española" de Bosque e Demonte (1999) ${ }^{5}$.

Para os dados do português usei os manuais de gramática de Bechara $(2001)^{6}$, de Cunha e Cintra $(1985)^{7}$ e a gramática de Mira Mateus $(1983)^{8}$.

Para o momento, não é o objetivo, realizar uma leitura crítica dessas gramáticas, apenas apontar como elas tratam as CEs tanto no português como no espanhol.

\footnotetext{
${ }^{3}$ REAL ACADEMIA ESPAÑOLA. Esbozo de una nueva gramática de la lengua española, 1973.

${ }^{4}$ GILI y GAYA, S. Curso superior de sintaxe espanhola, 1961.

${ }^{5}$ BOSQUE, I., DEMONTE, V. Gramática descriptiva de la lengua española, 1999.

${ }^{6}$ BECHARA, E. Moderna gramática da língua portuguesa, 2001.

${ }^{7}$ CUNHA, C.; CINTRA, L. F. L. Nova gramática do Português contemporâneo, 1985.

${ }^{8}$ MIRA MATEUS, M. H. et alli. Gramática da língua portuguesa, 1983.
} 


\subsection{HABER/TENER nos manuais de gramática do espanhol}

Nesta parte do trabalho, apenas farei uma pequena descrição de como os manuais de gramática tratam o assunto das construções com HABER e TENER no espanhol.

No espanhol, o verbo HABER faz parte da composição dos tempos compostos de todos os verbos (5) e (6); e forma as perífrases verbais com de/que + infinitivo (7) e (8).

5. Había comido mucho dulce, por esto le dolía la cabeza.

6. Has comido demasiado, pensé que estabas intentando perder peso.

7. Has de comer toda la comida si quieres pastel de chocolate.

8. Hay que comer de todo lo que se pone en la mesa.

Quando está na terceira pessoa do singular em frases sem sujeito e com um complemento, HABER indica existência, situação, acontecimento.

9. Habrá fiesta.

10. Hay nieve.

11. Había mucho por hacer ${ }^{9}$

A RAE (1973) e Gili y Gaya (1961) chamam este verbo de unipersonal. Os verbos unipersonales se diferenciam dos verbos impessoais, pois, com o sentido existencial, só aparecem na terceira pessoa do singular e nas formas não pessoais ${ }^{10}$. Fazem parte deste

\footnotetext{
${ }^{9}$ Exemplos 9 a 11- RAE (1973), "Esbozo de una nueva gramática de la lengua española”, Pág. 291. Meu grifo.

${ }^{10}$ Aqui chamo de formas não pessoais o infinitivo, o gerúndio e o particípio.
} 
grupo os verbos que indicam fenômenos da natureza (12), o HABER (13), o HACER (14) e o SER (15).

12. Llueve mucho ahora.

13. Había fiestas.

14. Hace calor

15. Es temprano.

Gili y Gaya (1961) explica que o verbo HABER (16) pode ter uma função existencial, equivalente aos verbos SER ou ESTAR (17).

16. No hay nadie.

17. No está nadie. ${ }^{11}$

18. Hay un hombre en la puerta.

19. Está un hombre en la puerta.

Esses dois últimos exemplos são interessantes porque podemos ver que HABER, assim como ESTAR, está esvaziado de significado. Em (16) e (18) HABER funciona como um verbo apresentacional. Trataremos melhor desse assunto ao analisar as CEs no espanhol.

Segundo a RAE (1973), o verbo HABER com valor transitivo, equivalente ao verbo TENER, está restrito à época antiga e clássica (20) e (21):

20. Mal haya mi suerte

\footnotetext{
${ }^{11}$ Exemplos 16 e 17 - GILI y GAYA (1961), pág. 78.
} 
21. Habida cuenta $^{12}$

TENER, no espanhol, é somente usado em seu sentido pleno, ou seja, como verbo de POSSE.

22. Juan tenía dos juguetes.

O esvaziamento de TENER não foi como o de TER. TENER em seu processo de gramaticalização, passou a abranger campos semânticos de HABER possessivo, mas, ao contrário de TER, não continuou avançando até ser compatível com HABER em todos os contextos.

$\mathrm{Na}$ formação de verbo auxiliar + particípio, se cria uma perífrase de significação perfectiva. Como dissemos, o verbo HABER seguido de particípio forma os tempos compostos do espanhol. O verbo TENER não pode ser usado como auxiliar no espanhol. Mas pode aparecer em sentenças nas quais o particípio se comporta como predicativo do objeto direto (OD) de TENER, por isso a concordância deste com o OD:

23. Tenía leídas muchas novelas semejantes.

24. $*$ Juan tiene sido soldado. ${ }^{13}$

25. Tenía la ensalada preparada.

Em (23), TENER LEÍDA é como se de alguma forma o sujeito possuísse, ainda de forma abstrata seu complemento. Note como em (23), em (25) e em (27) o complemento concorda com o predicativo (leídas, preparada e escritas), pois é seu

\footnotetext{
${ }^{12}$ Exemplos 20 e 21 - RAE (1973), pág. 292. Exemplo 21 é considerado arcaico pelos falantes do espanhol.

${ }^{13}$ Exemplos 23 e 24 - RAE (1973), pág. 449. Meu grifo.
} 
objeto direto. Ao contrário do que ocorre quando TENER é usado como auxiliar em (24) e em (26).

26. *José tiene escrito muchas cartas.

27. José tiene escritas muchas cartas.

Apesar de não compartilharem o mesmo sentido existencial no espanhol, o verbo HABER e o verbo TENER se comutam na formação de perífrases de expressão obrigatória:

$\begin{array}{ll}\text { Haber de }+ \text { infinitivo } & \text { He de premiar tu buena acción. } \\ \text { Haber que + infinitivo } & \text { Hay que tener paciencia. } \\ \text { TENER de + infinitivo } & \text { Tengo de decir la verdad. } \\ \text { TENER que + infinitivo } & \text { Tengo que estudiar. }\end{array}$

A diferença entre estas expressões obrigatórias é mais semântica que sintática. A primeira significa uma obrigação que o falante mesmo se impôs, não é tão enfática. Além disso, é mais antiga e mais literária que TENER QUE. A segunda é impessoal. A terceira hoje é antiquada e quase não se usa. A última, por sua vez, é a mais enérgica e intensa (RAE, 1973 e Gili y Gaya, 1961). O mesmo tipo de comutação ocorre no PB.

O verbo HABER também exibe certas restrições com relação ao efeito de definitude. O SN pos-verbal não pode ser precedido de um artigo definido, por exemplo, em qualquer contexto: 
28. a. *Hay el error en este libro.

b. Hay un error en este libro.

29. a. *Entre los invitados hay la conocida cantante.

b. Entre los invitados hay una conocida cantante.

c. Entre los invitados está la conocida cantante.

A explicação mais aceita para a agramaticalidade de (28a) e (29a) é que uma CE tem, antes de qualquer coisa, uma função apresentativa, dessa forma, a incompatibilidade surge porque o verbo HABER precisa de um complemento mais neutro com relação à existência, e um referente é completamente acessível dentro do discurso ${ }^{14}$. Intuitivamente, digo que a existencia de algo deve ser uma novidade dentro do discurso. Se uso um determinante, suponho que já é algo conhecido. Não havendo necessidade, então, de ser apresentado como novidade. Assim (28b) e (29b) são aceitos, pois os artigos indefinidos não contêm pressuposições sobre a existência do referente.

Aparentemente, HABER e TENER não estão tão distantes quando se trata do efeito de definitude, pois em construções como as de (30) o complemento também não pode ser definido, a não ser que este venha de alguma forma caracterizado por adjetivos por exemplo.

30. a. *María tiene el gato. $^{15}$

b. María tiene un gato.

\footnotetext{
${ }^{14}$ Leonetti, Manuel. (1999)

${ }^{15}$ Esta oração só é possível com o significado de posse transitória:
}

María está con el gato.

TENER apresenta um valor semelhante ao verbo original: "ter nas mãos", "sustentar". 
c. María tiene el gato más bello que he visto el toda mi vida.

Por outro lado, se mudarmos o SN complemento de HABER de posição na sentença, o efeito de definitude parece desaparecer quando o pronome relativo que está introduzindo uma oração restritiva:

31. a. El monumento que hay junto al parque está listo.

b. *Junto al parque hay el monumento.

32. a. Los quadros que había en el salón fueron guardados.

b. *En el salón había los quadros.

Entretanto, se que passa a introduzir uma explicativa o efeito de definitude volta a aparecer:

33. *El monumento, que hay junto al parque, está listo.

34. *Los quadros, que hay en el salón, fueron guardados.

As CEs no espanhol não são só realizadas com HABER, ESTAR também cumpre este papel. O mais interessante é que quando se trata de efeito de definitude ESTAR se comporta de forma totalmente inversa a HABER:

35. a. Aqui está (*hay) el regalo de Juan.

b. ? Allí están (hay) unos niños.

c. *En el parque están (hay) niños.

d. Los quadros, que están (*hay) en el salón, fueron guardados. 
Uma das explicações para este fenômeno é que, na verdade, as construções com HABER são existenciais, enquanto as construções com ESTAR são locativas. Ou seja, ESTAR pode introduzir um local específico, já está entendido que, ao indicar uma localização, teremos um sintagma definido. Por outro lado, a existência pressupõe algo que não estava antes no contexto, que não era conhecido, por isso deve vir introduzido por uma indefinição.

Entretanto, existem outros contextos nos quais o efeito de definitude parece não se aplicar:

36. No hay el menor indicio de culpabilidad.

37. Allí había la gente más rara que te puedes imaginar.

Nem sempre então o determinante é incompatível com a existência, o que na verdade causa a estranheza deve ser a necessidade, ou não, de um determinado elemento ser reentroduzido no contexto conversacional. Logo, para ser complemento de HABER deve existir uma informação nova, não compartilhada antes, dentro do contexto conversacional, entretanto, a definitude nem sempre é incompatível com este requisito. Isso esclarece porque a sentença em (30c) é boa, pois, o acréscimo de modificadores é a forma mais natural de tornar identificável uma informação nova para o ouvinte. Observemos os exemplos a seguir:

38. Incluso hay la perspectiva de que el viaje se pueda retrasar.

39. Hay el problema del aprovechamiento adecuado de los recursos. 
Assim, segundo Leonetti (1999) ${ }^{16}$ as restrições de definitude dependem tanto da diferença do que significa ser definido e indefinido quanto de questões do que está se informando e o que significa ser específico.

A maioria dos gramáticos concorda que o complemento de HABER deve ser um objeto, ou seja, recebe caso acusativo:

40. Hay helados.

41. Los hay

Como vemos em (40) e (41) podemos usar o pronome pessoal los para substituir helados na sentença, indicando que o complemento recebe caso acusativo.

Em "La gramática descriptiva de la lengua española" se afirma que as CEs com o verbo HABER são herdeiras de:

$$
<\text { habet impessoal }+ \text { acusativo }>
$$

Que se desenvolveram tardiamente no latim:

42. Habet in biblioteca Ulpia librum ete phantimum (Scriptores Historae Augustae, Vospicios, tac 8,1)

Outro ponto importante é que no espanhol de Santo Domingo HABER aparece acompanhado de um pronome neutro (ello) indicando que talvez no espanhol haja um preenchimento da posição de sujeito. O que pode nos levar a questionar que se na

\footnotetext{
${ }^{16}$ LEONETTI, M. (1999) “El artículo”. In.: BOSQUE, I.; DEMONTE, V (org).: Gramática descriptiva de la lengua española.’
} 
ausência desse pronome, poderíamos postular um expletivo nulo para preencher essa posição.

43. Ello no hay Dios si no cumplo mi palabra. (Quincito, 1934, Un amor tan guararé y pánico)

O verbo HABER também tem algumas diferenças entre seu SN complemento e os outros tipos de objetos diretos: não passiviza, deve ser indefinido (44-47), pode indicar distância (48), não pode ser acompanhado da preposição $a$ quando se refere à pessoas (49) e às vezes não acompanha um SN (49).

44. *Hay esos libros.

45. Hay un libro.

46. Hay tres libros.

47. *Hay todos los libros.

48. Había quatro metros desde la mesa hasta la pared.

49. En este bar hay $(* a)$ algunos professores.

50. Hay bastante con eso.

As CEs no espanhol se dão de forma diferente das CEs do português do Brasil (PB). É interessante observar o comportamento desses verbos (TER/TENER e HAVER/HABER) nas duas línguas, pois eles apresentam semelhanças e diferenças intrigantes.

O verbo TENER expressa relações de posse: 
51. María tiene tres gatos negros.

Pode ser usado para expressar posse transitória:

52. Juan tiene un paquete que es de mi hermano.

Pode ser usado também para expressar relação de posse substituindo, sem alterar o sentido prático da sentença, apesar de semântica e sintaticamente as estruturas serem completamente diferentes, em determinados contextos, o verbo HABER:

53. a. En tu biblioteca hay pocas novelas inglesas.

b. Tu biblioteca tiene pocas novelas inglesas.

54. a. En esta casa hay cinco ventanas.

b. Esta casa tiene cinco ventanas.

As construções em (53) e (54) são muito interessantes porque apesar de serem extremamente similares, o espanhol não faz uma ponte ligando HABER e TENER, assim como o português faz, ou seja, não houve um caminhar de TENER para o total esvaziamento, como caminhou HABER, TER e HAVER.

55. a. Na tua biblioteca há poucas novelas inglesas. - existencial

b. A tua biblioteca tem poucas novelas inglesas. - possessivo

c. Na tua biblioteca tem poucas novelas inglesas. - existencial 
56. a. Nesta casa há cinco janelas. - existencial

b. Esta casa tem cinco janelas. - possessivo

c. Nesta casa tem cinco janelas. - existencial

Alguns gramáticos consideram o verbo TENER um verbo leve, de apoio, pois pode expressar vários tipos de relações, inclusive que não sejam de posse. Entretanto, como pudemos observar, é difícil concordar que TENER seja tão leve quanto TER. É mais fácil pensar que TENER desde o latim até os dias de hoje ampliou sua abrangência lexical.

Nos capítulos posteriores iremos retomar essa questão a fim de deixar claro que TENER não é tão leve quanto TER, nos levando a pensar em níveis de esvaziamento semântico e sintático.

A seguir, coloco alguns exemplos para mostrar que TENER tem uma grade temática relativamente aberta:

57. Pedro tiene la nariz demasiado larga.

58. La nariz de Pedro es demasiado larga.

Como vimos nos exemplos (57) e (58), TENER pode ter uma grade semântica e sintática diferente da de posse, substituindo o SER. O exemplo (58) mostra que TENER em (57) está apenas ligando uma relação sujeito-predicado, ou seja, ele exerce a função de um verbo de ligação. Observe que se retirarmos o predicativo a sentença se torna agramatical:

59. *Pedro tiene la nariz. 
Outros exemplos que mostram que no espanhol TENER é um verbo ao menos ligeiramente leve são:

60. Tengo la casa patas para arriba.

61. *Tengo la casa estilo contemporáneo.

62. Ya tenemos leídos diez libros.

63. Tenemos a Juan enfermo.

64. *Tenemos a Juan inteligente.

65. *Tengo admirados dos actores de cine.

Em (60 e 62) TENER não tem um significado possessivo, ele pode ser substituído por LLEVAR (66). Nos exemplos acima, TENER implica em uma relação sujeitopredicado que denota ESTADO de coisas. Nos outros exemplos, podemos ver que apesar de ter uma grade semântica não tão rígida, ele não está completamente esvaziado de conteúdo, pois barra $(61,64$ e 65$)$.

66. Lleva diez libros leídos.

Como veremos nos capítulos seguintes, apesar de ter um comportamento não tão uniforme, TENER não chegou ao nível de esvaziamento de TER. Nem é usado como verbo auxiliar, nem é usado para as CEs. O que nos leva a pensar que de alguma forma o desenvolvimento de TENER foi "barrado" por HABER. Ou seja, HABER não continuou se esvaziando o suficiente para que TENER pudesse assumir as CEs e a posição de verbo auxiliar como TER assumiu no PB. 
Outro ponto interessante é que no espanhol também pode ocorrer o mesmo fenômeno que ocorre no português em situações coloquiais, o verbo HABER pode concordar numericamente com o único argumento:

67. Habían muchas personas en la fiesta.

68. Haviam muitas pessoas na festa.

Isso mostra que o falante pode ficar na dúvida de como marcar esse argumento único. Mas, assim como no português, o constituinte a esquerda é um adjunto de lugar/tempo o SN argumento se realiza internamente. E como o verbo HABER não atribui papel temático, este será dado através da relação entre os constituintes da coda ${ }^{17}$.

\footnotetext{
${ }^{17}$ Coda é composta dos constituintes de uma construção existencial, ou seja, o objeto e o adjunto de tempo/lugar.
} 


\subsection{HAVER/TER nos manuais de gramática do português}

Este capítulo se destina a apenas mostrar como são tratados os verbos TER e HAVER nos manuais de gramática do português. Para tanto uso os manuais de gramática de Bechara, Cunha e Cintra e Mira Mateus. Uma análise mais profunda das relações existentes entre esses verbos e seu(s) complemento(s) será feita alguns capítulos mais a frente.

No português do Brasil (PB), o verbo TER se comporta de maneira singularmente diferente do verbo TENER. Apesar de poder ter o mesmo valor que o verbo HAVER existencial, sendo considerado, deste modo, um verbo leve, TER também pode ser usado de forma plena, ou seja, significando POSSUIR. Observe os exemplos a seguir:

69. Tinha muitas pessoas na passeata de ontem. - existência

70. Havia muitas pessoas na passeata ontem. - existência

71. Eu tinha três livros deste autor. - posse

Além disso, no PB informal há casos em que o verbo, mesmo sendo impessoal, concorda com o único complemento da sentença, mostrando que não está clara qual é a função sintática ou semantica desse componente da sentença para os falantes nativos da língua:

72. Tinham muitas pessoas na passeata ontem.

73. Haviam muitas pessoas na passeata ontem. 
Ainda existem outros uso para o verbo HAVER no PB, a maior parte deles pode soar muito culta ou arcaica para os falantes, mas seu significado ainda pode ser interpretado. Passo agora a relatar alguns desses usos.

Cunha e Cintra (1985) apontam que o verbo HAVER ocorre em orações sem sujeito quando significa EXISTIR (74), como vimos anteriormente, e pode significar tempo decorrido (75):

74. Ainda há jasmins, ainda há rosas,

Ainda há vilões e modinhas

Em certas ruas saudosas. (Ribeiro Couto) ${ }^{18}$

75. Morava no Rio havia muitos anos, desligado das coisas de Minas. (C. dos Anjos) $)^{19}$

No PB, o verbo TER pode ser usado como substituto de HAVER nos dois casos acima, ou seja, ele pode ser impessoal, indicando existência (76), e também pode indicar tempo decorrido:

76. Em Pasárgada tem tudo, é outra civilização... (Manuel Bandeira) ${ }^{20}$

77. Tem muitos anos que ele mora nessa casa, ela pertencia a seu avô.

\footnotetext{
${ }^{18}$ CUNHA e CINTRA (1985), pág. 126. Meu grifo.

${ }^{19}$ Ibid, pág. 126. Meu grifo.

${ }^{20} \mathrm{Ibid}$, pág. 127. Meu grifo.
} 
TER e HAVER também podem ser comutados quando são usados como um verbo auxiliar (78) e (79):

78. Tinha caído durante os exercícios.

79. Havíamos comprado livros.

Quando são auxiliares, os verbos TER e HAVER mostram que passaram por todo processo de gramaticalização, ou seja, se esvaziaram de seu significado e agora carregam o aspecto de modo e de tempo da sentença. Veremos com mais detalhes esse esvaziamento alguns capítulos mais a frente.

Assim, os verbos TER e HAVER se combinam com verbos no particípio para formarem os tempos compostos da voz ativa: do indicativo (pretérito perfeito composto, pretérito mais-que-perfeito composto, futuro do presente composto, futuro do pretérito composto), do subjuntivo (pretérito perfeito, pretérito mais-que-perfeito, futuro composto) e as formas nominais (infinitivo composto e gerúndio composto) (Bechara, 2001).

Cunha e Cintra (1985) ainda ressaltam que o verbo HAVER pode ser usado em todas as pessoas ou apenas na terceira pessoa do singular, dependendo do seu significado. Usado como auxiliar (80) e como verbo principal com significado de ALCANÇAR (81), usado na forma reflexa, significa PROCEDER (82), ENTENDERSE (83) ou acompanhado de infinitivo sem preposição, significa SER POSSÍVEL (84):

80. Outros haverão de ter

O que houvermos de perder. (Fernando Pessoa) 
81. Donde houveste, ó pélago revolto,

Esse rugido teu? (Gonçalves Dias)

82. Soares houve-se como pode na singular situação em que se achava. (Machado de Assis)

83. O mestre padeiro, que era do mesmo sangue do patrão, que se houvesse com ele. (J. Lins do Rego)

84. Não há negá-lo, o apito é de uso geral e comum. (Machado de Assis) ${ }^{21}$

É importante ressaltar que esse esses usos (80 a 84) do verbo HAVER são considerados arcaicos para um falante do PB atual.

Quando os verbos TER e HAVER são usados como auxiliar, acompanham o núcleo do sintagma verbal (SV), à sua esquerda, expressam tempo (85 e 86), aspecto e modalidade (87-89).

85. Tinha saído quando tu chegaste

86. Hei de ir lá para a semana. ${ }^{22} 23$

87. Tenho de sair esta noite.

88. Tenho que sair esta noite.

89. Há que fazer este trabalho dê por onde der. ${ }^{24}$

\footnotetext{
${ }^{21}$ Exemplos 29 a 33 - CUNHA e CINTRA (1985), págs. 525 e 526. Meu grifo.

${ }^{22}$ Exemplos 34 e 35 - MIRA MATEUS, M. H. (1983), pág. 284. Meu grifo.

${ }^{23}$ Da forma em que estão exemplos 85 e 86 , somente o primeiro entra na formação dos tempos compostos. O segundo é utilizado para exprimir o futuro em relação ao passado ou ao presente (Mira Mateus, 1983).

${ }^{24}$ Exemplos 36 a 38 - Ibid, pág. 285. Meu grifo.
} 
Assim como no espanhol, no português os verbos TER e HAVER formam os auxiliares modais, que indicam obrigatoriedade de uma ação. Desde o ponto de vista do falante, os exemplos (87) e (88) expressam uma obrigatoriedade de fora para dentro, ou seja, uma obrigação que de alguma forma foi imposta externamente ao falante. Por outro lado, o exemplo (89), com o verbo HAVER, indica uma obrigatoriedade inversa, ou seja, de dentro para fora, que foi imposta pelo próprio falante.

Além destes usos, o verbo HAVER também se cristalizou nas seguintes expressões: haver por bem, significando resolver (90) e haver mister, significando precisar (91), mais uma vez essas expressões são arcaicas e pouco usadas no PB atual:

90. O coronel, que neste momento lia na rede as folhas recém-chegadas, houve por bem interromper a ingestão de um flamante discurso sobre a questão do Amapá para acudir em apoio ao fedelho. (Monteiro Lobato).

91. Deus o auxilie e ilustre, e a todos nós, quem bem o havemos mister. (Almeida Garrett). ${ }^{25}$

Quanto ao seu uso na terceira pessoa do singular, ou seja, como impessoal, já esclarecemos que ocorre quando tem o mesmo significado de existência ou quando indica tempo decorrido. Quando acompanhado dos auxiliares ir, dever, poder etc. e exprimindo existência, forma uma locução impessoal (92):

92. Podia haver complicações, quem sabe? (C. dos Anjos) ${ }^{26}$

\footnotetext{
${ }^{25}$ Exemplos 909 e 40 - CUNHA e CINTRA (1985), pág. 527. Meu grifo.

${ }^{26}$ CUNHA e CINTRA (1985), pág. 528. Meu grifo.
} 
É importante ressaltar que mesmo tendo a mesma significação, o verbo HAVER e o verbo EXISTIR se comportam de modo distinto no que diz respeito a sintaxe, ou seja, o verbo EXISTIR nunca é impessoal, possui sujeito e, por tanto, concorda com ele:

93. Há tantas folhas pela calçada.

94. Existem tantas folhas pela calçada. ${ }^{27}$

\footnotetext{
${ }^{27}$ Exemplos 932 e 943 - CUNHA e CINTRA (1985), pág. 528. Meu grifo.
} 
CAPÍTULO 3 


\section{Descrição diacrônica}

Neste capítulo faço uma descrição de como eram usados os verbos TER e HAVER no português arcaico e TENER e HABER no espanhol arcaico. O objetivo é colher dados para uma futura comparação entre o uso de antes e o uso de hoje, a fim de verificar quais foram as mudanças estruturais que ocorreram com cada um desses verbos.

Para os dados do português arcaico uso principalmente os trabalhos de Matos e Silva (1971, 1991, 1994, 1996, 2001).

Para a descrição diacrônica do espanhol arcaico uso o trabalho de Lapesa (1981), Cano (1992, 2002), Hansen (1945), Hernández Diaz (2006) e Menendez Pidal (1944, 1950, 1966, 1968). O mais recente e detalhado trabalho sobre as estruturas existenciais e de posse do espanhol antigo é o de Henández Diaz (2006) e, exatamente por isso, será mais detalhadamente discutido neste capítulo. 


\subsection{O português arcaico}

Nesse capítulo tomo por base os estudos já publicados de Rosa Virginia Mattos e Silva para o desenvolvimento sintático e semântico dos verbos TER e HAVER.

No latim, o verbo que indicava posse era o HABERE, significando 'ter em sua posse'. O verbo TENERE significava ‘sustentar', ‘ter na mão’. Daí, já se pode observar que no latim o campo semântico dos dois verbos era muito próximo.

A respeito dos tempos compostos com HAVER e TER no português arcaico, Mattos e Silva (1994) afirma que eles só foram possíveis depois que o particípio perdeu as suas desinências pessoais, ou seja, quando não concorda mais com o complemento direto. Antes disso, o sentido de posse destes dois verbos fica evidenciado (95-98).

95. Todoslos bēēs que mh'á feitos. (séc. XIV)

96. Aquelas cousas que ten aparelhadas. (séc. XIV)

97. Os serviços que avian feitos a seu padre.

98. Non ousaron d'entrar na camar por a defesa que el rei tinha posta. ${ }^{28}$

Na primeira metade do século XV já começa a existir uma variação na concordância do particípio, dentro de um mesmo documento é possível encontrar os dois usos (99):

99. E non sabedes quanto afam e trabalho avedes tomado e quantas espadadas e seetadas havedes levadas. ${ }^{29}$

\footnotetext{
${ }^{28}$ Exemplos 954 a 987 - MATTOS e SILVA (1994), pág. 64.

${ }^{29}$ Ibid, pág. 65.
} 
avedes tomado - HAVER como verbo auxiliar

havedes levadas - HAVER como verbo pleno, indicando posse.

Assim, somente é possível que haja tempos compostos quando o verbo HAVER se esvazia de seu significado de posse. Para a autora conclui que a estrutura do tempo composto vai se consolidando a partir da primeira metade do século XV e se firma no século XVI.

No português arcaico as impessoais se realizavam com os verbos HAVER (101) e SER (100) e FAZER (102) (indicando tempo ou fenômeno da natureza) ou por verbos que indicassem fenômenos naturais (103).

100. Na cidade d'Aconha foi hũũ bispo de gram santidade.

101. Non avia padres santos.

102. O rio saia da madre quando fazia as chúvias mui grandes.

103. Mandou que chovesse. ${ }^{30}$

O HAVER existencial vinha muitas vezes acompanhado de um locativo $h i, i, y^{31}$ :

104. Quem hi ha tam acabado que todo perfeitamente diga e faça?

Segundo Mattos e Silva (1994), somente mais recentemente o verbo TER é usado como existencial, concorrendo com o HAVER e o EXISTIR. Nos séculos XIV e XV, os verbos TER e HAVER também concorriam (ainda que não de modo livre) com uma mesma função. Entretanto, não era a função existencial, mas sim a de posse. $\mathrm{O}$ verbo

\footnotetext{
${ }^{30}$ Exemplos 49 a 52 - ibid, pág, 64.

${ }^{31}$ No espanhol, o locativo se fixou ao verbo no presente: hay.
} 
HAVER ocorria com complemento de qualquer valor semântico - bens materiais (105) e qualidades imateriais (106) adquiríveis e qualidades intrínsecas ao sujeito (107).

105. (h)aver pan, remedio, horto, bispado, logares, morada casa ovelhas 106. (h)aver fe, graça, poder, poderio, medo, voontade, avondança, door 107. (h)aver barvas, ceguidade, cinquenta anos, enfermidade.

Entre os séculos XIV e XV, o verbo TER comuta livremente com o HAVER na primeira construção - bens materiais - (108) e raramente na segunda - abstratos.

108. teer cireos, espada, cavalo, candea, meezinha, arca, logares, caneiro

A partir do século $\mathrm{XV}$, os verbos comutam nas três construções, sendo que o HAVER é mais comum (109).

109. haver/ter cousas; haver/ter paz; haver/ter oolhos

É provavelmente no século XVI que o verbo TER substitui o HAVER deste tipo de construção.

No português arcaico, como descrevemos anteriormente, o verbo TER começa a substituir o HAVER justamente quando este designa 'possuir bens materiais', difundindo-se para os outros contextos. Desta forma, o verbo HAVER se especializa em construções existenciais e o TER em predicados atributivos possessivos. Atualmente, o verbo TER também está tomando o lugar do HAVER nas construções existenciais em algumas variantes faladas do português. 
TER não parou seu processo de esvaziamento, como TENER parou no espanhol. Como veremos nos capítulos posteriores TENER é considerado por alguns gramáticos do espanhol como um verbo leve, mas se comparado com TER, TENER ainda guarda muita carga semântica. 


\subsection{O espanhol arcaico}

Aqui irei apresentar a evolução diacrônica dos verbos TENER e HAVER no espanhol.

Os verbos AVER e TENER disputavam o mesmo espaço quando eram transitivos e significavam posse. Assim como no português arcaico, se usava AVER quando o objeto direto era abstrato (110) e TENER, quando concreto (111). Além disso, o AVER indicava "obter", “conseguir”, "lograr” e o TENER, “estar em posse de algo", "reter”, "manter". Entretanto, esses limites não eram fixos (assim como vimos no português) e havia uma constante interferência nos campos semânticos.

110. Aver pavor, duelo, fambre.

111. Un sombrero que tiene Félez Muñoz. ${ }^{32}$

Durante o processo de gramaticalização TENER não se esvazia como TER e HABER segue se esvaziando assim como HAVER. É interessante notar que no mesmo período, séculos XIII, XIV e começo do XV, o português e o espanhol usam os verbos AVER e TENER da mesma forma, ou seja, o processo evolutivo do espanhol e do português arcaico HAVER e HABER e TER e TENER exerciam as mesmas funções nos mesmos contextos.

Segundo Lapesa (1981), nos tempos compostos com AVER, o particípio podia ou não concordar com o objeto direto. O mais comum era a concordância (112), mas também há exemplos de seu uso atual (113).

\footnotetext{
${ }^{32}$ Exemplos 110 e 111 - LAPESA, Rafael (1981).
} 
112. La avemos veída e be[e]ne percebida.

113. Tal batalla avemos arrancado. ${ }^{33}$

Da mesma forma, esses dois verbos formavam os tempos compostos do espanhol $\operatorname{arcaico}(114)$.

114. sodes llegados, avedes 1legado. ${ }^{34}$

\subsubsection{O espanhol arcaico segundo o trabalho de Hernandez Diaz}

Nesta seção vou apresentar o trabalho de Hernández Diaz $(2006)^{35}$. Ela faz um estudo sobre as construções possessivas e as construções existenciais no espanhol arcaico. Primeiramente apresentarei seu trabalho, depois faço algumas observações sobre seus métodos e conclusões.

Esse trabalho é relevante principalmente por apresentar de forma detalhada o uso das sentenças com TENER e HABER no espanhol arcaico.

\subsubsection{Introdução}

Hernández Díaz (2006) publicou um artigo no qual estuda minuciosamente uma série de características de sentenças possessivas e existências do espanhol arcaico que em sua opinião foram relevantes para a mudança e evolução das CEs e das construções possessivas (CPs) na Língua Espanhola.

\footnotetext{
${ }^{33}$ Exemplos 112 e 60 - LAPESA, Rafael (1981) pág. 212.

${ }^{34}$ LAPESA, Rafael (1981), pág. 217.

${ }^{35}$ HERNANDEZ DIAZ, Axel. (2006) "Posesión y existencia: la competencia de haber y tener y haber existencial”. In.: COMPANY, C.C. Sintaxis histórica de la lengua española: primera parte: la frase verbal. V.1
} 
A autora começa descrevendo o comportamento de cada verbo desde o século XII até o século XVI.

No séc. XII, quando o objeto direto (OD) é concreto, ambos os verbos podem ser interpretados nos seus valores originais: TENER é "sustentar", "ter na mão" e HABER é "possuir".

115. Alegres son por Valençia las yentes cristianas/ Tantos auien de aueres, de caballos e de armas/ Alegres es doña Ximena e sus fijas amas [Cid, 1800]

116. al salir dela ecclegia cabalgaron tan priuado, / Ala glera de Valençia duera dieron salto; / Dios, que bien touieron armas el Cid e sus vassalos! [Cid, 2243]

No Séc. XIII, HABER aparece para expressar relações possessivas metafóricas, irreais, possíveis, prováveis, ou seja, praticamente todas as relações de posse. TENER prefere situações reais, predicações com sujeito especifico e com copretérito do indicativo.

117. Dos son los que veen: el que ha los ojos claros et el sábio [Calila, 293]

118. Dicen que un rey muy poderoso tenía una ave que dezían Catra. [Calila, $272]^{36}$

\footnotetext{
${ }^{36}$ Todos os exemplos citados no ponto 3.2.1 são apresentados no trabalho de Hernández Díaz (2006)
} 
O Séc. XIV confirma as tendências do século anterior para os usos de TENER e HABER. Mas já se pode notar que TENER está expandindo seu território sendo documentado em situações iguais a de HABER.

119. las gentes suyas non podian aver viandas ni mantenimientos [Enrique II, 371]

120. Otrossy por la mar el rrey no fuera aperçebido e non tenian viandas ni nauios [ Enrique II, 370]

Tanto em (119) como em (120), viandas é usado como complemento de TENER e de HABER, mostrando que no mínimo podíamos apontar uma alternância de HABER e TENER no período.

No Séc. XV, a expansão de TENER continua enquanto começam a aparecer HABER existenciais sem ambigüidade.

121. todos los que al rey don Enrique seguian estorvavan esto porque su tiranía oviese mas lugar [Enrique IV, 251]

122. el rey Çiriça dde Granada vino fazer reverencia al rey, el qual tenia algunos lugares assaz çerca de Malaga, aunque la çibdad le er contraria e quesiera excussar el daño dellis [Enrique IV, 31]

E, finalmente, no Séc. XVI, TENER tem a preferência nas construções possessivas e HABER aparece em CEs. 
123. porque Nuestro señor lo tiene ordenado de outra manera, y quiere que baya encaminado por mano de vuestra majestad, para que asi baya mejor guiado y aya mejor effecto. [DLNE, 1563, 29.146]

124. para que mejor effecto tubiese este negocio, vuestro visorrey, deseoso del serviejo de Nuestro Señor y de vuestra majestad, se ofrecio a gastar de su hazienda lo que no tenia. [DLNE, 1563, 29.146]

No espanhol antigo, HABER foi perdendo seu valor possessivo e se tornando ambíguo, variando entre posse e existência, até ser usado somente para existência e como verbo auxiliar. Segundo, Hernández, HABER em CPs foi gradualmente substituído por TENER, até que nos séculos XIV e XV TENER passa a ser o preferido para as CPs.

Para Hernández Diaz, TENER vai ampliando seu quadro de relações semânticas enquanto HABER mostra restrições com relação a seus complementos. A fim de entender essas mudanças a autora passa a analisar a natureza desses complementos em busca de explicações para a preferência de TENER sobre HAVER.

Deste modo, passa a ser importante analisar os complementos existentes em cada tipo de construção para poder desta forma estabelecer quais são os fatores que vão influir na mudança gramatical de cada verbo, já que os vínculos existentes entre as relações possessivas $[+$ concretas] e [+abstratas] se estabelecem mediante processos metafóricos baseados na conceptualização do individuo, de atributos e de sentimentos, entre outros, passíveis de serem possuídos:

125. Yo tuve miedo (relação [+abstrata]) 
126. Ella tiene pelo negro. (relação [+concreta])

Na próxima seção irei comentar alguns dos fatores apontados por Hernández Díaz que pareceram ser mais relevantes na mudança.

\subsubsection{A análise de Hernández Díaz}

A autora nota que, nos séculos XIII a XIV, HABER vai ser usado preferencialmente quando o sujeito está implícito, o OD é abstrato e pertencente ao mundo dos sentimentos; quando se trata de posse inalienável, ou seja, quando o possuído pertence ao domínio pessoal do possuidor, e este não pode se conceber sem aquele (parentesco, partes do corpo e nome).

TENER, por sua vez, é usado com sujeito explicito [+agentivo] e OD [+concretos] e [+contáveis]; com situações de posse alienável, de tipo extrínseco, as entidades podem mudar, serem vendidas ou deixar de ser possuídas. Outros autores, como Lapesa (1981), para o espanhol, e Mattos e Silva (1994) para o português, já tinham observado este fenômeno.

A autora apresenta alguns motivos para a mudança de HABER por TENER:

- Baixa transitividade

Para Hernández Díaz, HABER é um verbo estativo e por isso tem uma taxa de transitividade baixa, sua função era estabelecer uma ligação de um individuo e um objeto de sua esfera pessoal. Como na maioria das vezes o verbo HABER tem como um OD algo abstrato, o sujeito da sentença é quase um experimentador, como em: 
127. Haber miedo.

Com a evolução de TENER, HABER possessivo fica cristalizado a algumas frases feitas: haber menester.

Segundo ela, TENER também é um verbo estativo, mas é mais transitivo que HABER, usado somente para indicar posse, ao contrario de HABER, que por ser muito polissêmico (ou seja, usado em muitos contextos diferentes como posse, existência e como verbo auxiliar) perdeu força. Analisando os dados recolhidos, a autora afirma que TENER vai mudando seu campo semântico de atuação.

Entretanto, a baixa transitividade de HABER não pode ser a causa da mudança. Afinal, no português TER mantém tanto seu significado de posse, quanto o de existencial e o de auxiliar e nenhuma das leituras se vê "prejudicada" por outra. Outro ponto a ser levado em consideração é que se baixa transitividade gerasse por si só mudanças, os verbos intransitivos sofreriam alterações, o que não ocorre.

- Polissemia de HABER

Apesar de Hernández Diaz apontar a polissemia como uma das prováveis causas do esvaziamento de HABER, creio que esta não deva ser a única explicação. Como apontamos anteriormente, no PB, apesar de TER ser usado para posse, para existência e como auxiliar, o valor possessivo continua forte. A polissemia de uma determinada palavra, seja um verbo ou um substantivo, não deve ser responsável por uma mudança radical, normalmente as línguas naturais tendem a conviver de modo pacífico com a polissemia, que costuma ser abundante. 
- Falta de flexibilidade das relações possessivas com HABER. Flexibilidade semântica e sintática de TENER possessivo.

Para a autora, com a ampliação da grade temática de TENER, HABER ficou menos flexível com relação a seus complementos. Entretanto, isso não explica como HABER, que antes era responsável por todas as relações de posse, passou a aceitar somente um determinado tipo de complemento.

Ainda com relação à concorrência entre TENER e HABER. Para Hernández Díaz, TENER foi ampliando sua grade semântica fazendo com que HABER fosse restringindo seu uso. Entretanto, TENER tinha um significado possessivo ainda no latim. HABER, por outro lado, sofreu muitas mudanças temáticas e sintáticas.

Sendo assim, creio que seria mais correto afirmar que enquanto HEBER restringia sua grade temática, TENER ampliava seu uso e não que TER ampliava por isso que HABER restringia, como coloca Hernández Díaz.

- As características dos argumentos também são essenciais para a mudança.

É nas características dos argumentos que Hernández Díaz vai concentrar a maior parte de sua análise. Ela detalha cada tipo de OD e como eles poderiam influir na grade semântica de seus verbos. Os traços mais relevantes foram [+/-animados] [+/concretos], [+/-contáveis], [+/-determinados], posse alienável e posse inalienável.

Para Hernández Díaz, algumas perguntas devem ser feitas com relação ao complemento de HABER e de TENER. Passo a descrever algumas dessas perguntas e as respostas encontradas por ela. 
O OD apresenta ou não determinantes? A maioria dos dados apresentados por Hernández Díaz aparece sem o uso de determinantes, principalmente com HABER, talvez por estar relacionado à OD abstratos. TENER se emprega em um maior número de ocasiões com OD determinados por artigos, possessivos ou demonstrativos.

Com relação ao número, singular ou plural, para a autora, HABER aceita um maior número de OD no singular que TENER, provavelmente por serem abstratos. TENER por ser mais flexível aceita mais o plural. Ela afirma também que a maior parte dos ODs com determinação são singulares, já que o plural é, por natureza, mais genérico.

Outro fator da mudança estaria nos sujeitos de HABER e TENER. Com relação à presença de um sujeito e a possibilidade do leitor recuperá-lo através do verbo, quanto menor a ambigüidade de uma sentença, menor a possibilidade do verbo ser interpretado como existencial e mais claro está seu significado de posse.

Se HABER aparece mais vezes sem o sujeito e tem maior dificuldade de recuperálo, maior a possibilidade de ocorrer uma CE. Se, por outro lado, TENER aparece mais vezes com o sujeito e existe maior facilidade de recuperá-lo, menor a possibilidade de uma CE. Assim, a presença ou ausência do sujeito é relevante para a gramaticalização. TENER está presente com seu sujeito muito mais que HABER, fator que pode ter incentivado as existenciais com HABER ${ }^{37}$. Isso significa basicamente que quanto maior a possibilidade de recuperação do sujeito menor a possibilidade do verbo ser interpretado como existencial.

A autora afirma que TENER recupera com maior facilidade os sujeitos próximos por serem [ + agentivos], mas é a recuperabilidade não próxima que gera maior ambigüidade. Entretanto, ao analisar o quadro das porcentagens de recuperabilidade do

\footnotetext{
${ }^{37}$ Se TER se usasse sempre com o sujeito próximo e explícito não seria impessoal na Língua Portuguesa.
} 
sujeito, notei que TENER tem maior dificuldade de recuperar sujeitos distantes, o que levaria a supor que ele se realizasse mais vezes com o sujeito explicito que HABER, mesmo por causa da marca de agentividade que o sujeito carregava.

Aliás, TENER sempre indica uma sentença possessiva, ainda que o sujeito seja oculto ou indeterminado o verbo sempre o recupera. Em "La Celestina" há um exemplo muito interessante para ilustrar esse ponto:

128. E yo no seruí al cura de Sant Miguel e al mesonero de la Plaza e a Mollejar, el ortelano? E tambien yo tenía mis questiones con los que tiravan piedras a los paxáros, que assentavan en un álamo grande que tenía, porque danavan la ortaliza. ${ }^{38}$

Tenía em (128), não pode ser um verbo impessoal. Deve, necessariamente, ter um sujeito, ainda que este esteja longe, a capacidade de recuperação deste referente é alta com TENER. No caso do exemplo anterior, tenía se refere ao ortelano, Mollejar.

Para Hernández Díaz, os resultados também indicam que os complementos circunstanciais são um fator importante no processo de mudança, pois, para ela, a existência, a locação e a posse estão relacionadas entre si.

No inicio dos períodos estudados por Hernández Díaz, os complemento circunstanciais aparecem tanto com HABER quanto com TENER de modo equivalente, entretanto HABER logo vai dispensando esse complemento. A autora interpreta este fenômeno como um reflexo dos ODs de HABER serem na sua maioria abstratos, o que diminuiria a necessidade ou a compatibilidade com domínios espaciais reais.

\footnotetext{
${ }^{38}$ ROJAS, Fernando. La celestina. Volume 2. Madrid. Ed.: La lectura. 1913. Ato 12, pág. 90, lin. 16.
} 
Aparentemente, tanto HABER quanto TENER diminuem sua preferência por aparecer com complementos circunstanciais. A diferença está no fato de que em HABER esta queda foi maior que em TENER (de $40 \%$ no séc. XII para $15 \%$ no século XIII para HABER e $42 \%$ para $24 \%$ em TENER nos mesmos séculos).

No período medieval, em algumas ocasiões não é possível distinguir posse de existência. Para a autora, a CE ainda tem um valor transitivo, mas seu agente está de alguma forma diluído no contexto. Para ela, ao tratar de textos medievais, quando o possuidor, ou candidato a possuidor é [+humano] a leitura existencial pode ficar prejudicada dando-se preferência à leitura possessiva, mas quando o "possuidor" é [humano] a leitura existencial é preferencial.

Para a autora, a CE ainda tem um valor transitivo, mas seu agente está, de alguma forma, diluído no contexto. Entretanto, creio que o possuidor não pode ser caracterizado como agente, ele é mais um experimentador ou beneficiário; em uma ralação de posse não existe modificação do OD pelo sujeito.

Para ela, ao tratar e textos medievais, quando o possuidor, ou candidato a possuidor é [+humano] a leitura existencial pode ficar prejudicada dando-se preferência à leitura possessiva, mas quando o "possuidor" é [-humano] a leitura existencial é preferencial. Essa afirmação é problemática, pois é possível haver um sujeito [-humano] e [-animado] como possuidor de algo. Observemos os exemplos a seguir:

129. Hay rosas en el jardín.

130. El jardín tiene rosas. 
Assim, o verbo HABER teve, e segue tendo, um comportamento peculiar no espanhol. Graças a sua baixa transitividade participou de muitos processos evolutivos (existência, futuros, verbos compostos) e também propiciou zonas férteis para a mudança lingüística dada a sua natureza abstrata.

Podemos concluir então que resta muito que explicar no que diz respeito às CEs no espanhol. O trabalho de Hernández Díaz tem o mérito de suscitar mais questões para serem respondidas. Com o desenvolvimento de meu trabalho pretendo responder à algumas dessas perguntas e esclarecer um pouco mais sobre a sintaxe e a semântica das CEs no espanhol. 
CAPÍTULO 4 


\section{Uma proposta de análise para o verbo TER}

Neste capítulo apresentamos algumas propostas de análise que podem ser úteis para compreender melhor a estrutura do verbo TENER tanto no espanhol corrente como na sua realização arcaica.

Especificamente, com relação ao verbo TER iremos discutir alguns pontos da proposta de Viotti (1999) “A sintaxe das sentenças existenciais no português do Brasil”. Para servir de apoio à proposta de Viotti, iremos também apresentar um artigo de Franchi et alii (1998), do qual a própria Viotti participa.

Outra análise que nos ajudará a entender como se formam as construções existenciais é a proposta do léxico gerativo de Pustejovsky (1998). Como ele não fala especificamente sobre as construções com o verbo TER, sua proposta será brevemente apresentada e não me deterei em discuti-la profundamente. 


\subsection{Introdução}

Existem, para o português do Brasil (PB), inúmeros estudos sobre as construções existenciais. Entretanto, a maioria desses estudos é de natureza descritiva, histórica ou discursiva. O objetivo desse trabalho é apresentar tanto para o $\mathrm{PB}$, como para o espanhol, uma análise mais profunda das relações sintáticas e semânticas.

Vou me basear nas análises de Viotti (1999), no seu estudo sobre o verbo TER, para considerar a possibilidade de uma análise em pressupostos teóricos semelhantes para o verbo espanhol TENER.

Viotti segue conceitos expostos por Franchi et alii (1998) e noções fundamentais da proposta de Pustejovsky (1998) para a análise dos eventos. Assim sendo, Para um melhor entendimento e fluência da dissertação, vou apresentar, primeiramente, um artigo publicado na revista DELTA (1998). Deste artigo participam os professores Carlos Franchi, Esmeralda Negrão e Evani Viotti. Depois falaremos em pouco sobre a teoria de léxico gerativo de Pustejovsky e, por último, trataremos da proposta de Viotti para as CEs com o verbo TER no PB. Desta forma, as propostas seguem nessa ordem:

- Franchi et alii (1998), Negrão e Viotti (1998) em “A gramática das orações impessoais com TER/HAVER” publicado na revista DELTA.

- Pustejovsky (1998) em “The semantics of lexical underspecification”.

- Viotti (1999) em “A sintaxe das sentenças existenciais do português do Brasil”, sua tese de doutorado e "A composicionalidade nas sentenças com o verbo 'ter"” publicado no livro Semântica formal. ${ }^{39}$

\footnotetext{
${ }^{39}$ VIOTTI, Evani, em Müller, A. L.; Negrão E.V. e Foltran, M. J. (orgs) 2003.
} 


\subsection{Idéias sobre as construções impessoais com o verbo TER de Franchi et alii (1998)}

Franchi et alii (1998) trabalha com o conceito de predicação. Predicação é uma relação de sentido que se estabelece entre as expressões lingüísticas. A relação de predicação é determinada exclusivamente pelas propriedades semânticas dos itens lexicais, que podem ser simples ou complexas. Qualquer categoria lexical capaz de predicar (Verbo, Nome, Adjetivo, Advérbio e Preposição) deve estabelecer uma relação de predicação com os sintagmas a ela relacionados.

Tanto o processo interpretativo, quanto a possibilidade de realização de determinadas estruturas sintáticas são condicionadas pela combinação dos itens lexicais em objetos sintáticos e não somente pelas propriedades formais e semânticas desses itens.

A predicação ocorre toda a vez que um par de expressões semanticamente compatível for combinado. As relações temáticas de determinadas predicações são o resultado do acarretamento e pressuposições gerados pelo fato de uma ou mais expressões lingüísticas terem se relacionado. Os argumentos são diferenciados entre si dependendo a que qualificação do predicador eles vão se associar.

Assim sendo, o que faz com que as sentenças tenham uma interpretação é a análise composicional do conteúdo semântico dos itens lexicais que a constituem.

131. a. O menino quebrou o vaso

b. O menino quebrou o braço

Composição do complemento. 
Em (131a) o sintagma o menino recebe um papel temático de agente por sua ação de quebrar o vaso. Ao mudar o objeto em (131b), o menino passa a ser Experienciador de quebrar o braço.

E como Franchi et alii (1998) vão tratar as CEs com o verbo TER? Observemos a sentença (132):

132. [Tinha] [[um gato preto] [perto dela]].

Para Franchi et alii (1998), o verbo TER é um operador funcional, portador de dêixis temporal e aspectual. A predicação na verdade é estabelecida entre a relação dos constituintes da coda (o argumento e o predicado secundário). Sendo assim, no exemplo (132); o verbo TER é o operador funcional, ele é encarregado de indicar o tempo e o aspecto da sentença, mas não atribui papel temático. A relação de predicação realmente ocorre entre os elementos da coda: um gato preto e perto dela.

Sentenças com o verbo TER existencial tem uma função apresentacional, elas introduzem novas entidades no universo do discurso.

133. [Tem] [[folhas de mangueira] [no chão]].

Verbo: operador de tempo e aspecto da sentença apresentada (coda).

Coda: há uma relação de predicação entre seus constituintes

Função: apresentacional, introduz novas entidades no universo do discurso.

Dentro da língua portuguesa, as CEs com TER são uma particularidade do PB. Se TER e HAVER compartilham os mesmos contextos em CEs, como podemos verificar que de fato compartilham, essas sentenças no PB apresentam dois problemas: 
I. O constituinte a esquerda é um adjunto de lugar/tempo; o SN argumento se realiza internamente.

II. Não há como falar de uma relação semântica de predicação. TER/HAVER não atribuem papel temático ao SN argumento interno.

Então, o papel temático é atribuído através da relação entre os constituintes da coda (veremos um pouco mais sobre isso a seguir). Outras informações, como tempo e aspecto, são dadas pelo verbo existencial.

Para Franchi et alii (1998), a interpretação depende componencialmente, do sentido dos sintagmas nominais e preposicionados que formam as expressões, entre as quais o verbo TER expressa uma relação muito abstrata e inespecífica, por isso pode ser usado como existencial. Para mim, o mais intrigante a respeito do TER é que ele ainda mantém bem presente seu sentido de posse.

Nas CEs, TER e HAVER tem uma função estritamente operacional (apresentacional, no caso) não há relação temática. Se houvesse uma relação temática entre o verbo e os outros elementos da coda teríamos uma relação de predicação e não uma sentença apresentacional. No caso das sentenças aqui estudadas a relação temática ocorre entre os constituintes da coda e não entre o verbo e seu argumento.

Resumindo, a estrutura de um verbo que passou por um processo de dematização ou impessoalização é: ausência de argumento externo, argumento interno focalizado, não concordância do verbo com este argumento, predominância do SN-indefinido, função discursiva apresentacional. ${ }^{40}$ Por isso, a estrutura das seguintes sentenças é muito parecida:

\footnotetext{
${ }^{40}$ A estrutura de DAR resultativo se assemelha muito com a de TER impessoal:

- Dá umas nanicas enormes na minha chácara,

- Tem umas nanicas enormes na minha chácara. (exemplos retirados de Franchi et alii (1998))
} 
134. O verão tem tudo que é fruta

135. No verão tem tudo que é fruta.

A sentença em (135) é o resultado da detematização de um argumento o verão da sentença em (134).

Assim para Franchi et alii (1998), sintaticamente, as CEs com TER e HAVER devem ser vistas como estruturas impessoais, diferentes das CEs com EXISTIR que possuem dois argumentos (externo e interno) ou apenas um argumento interno:

136. Existe Deus.

Nas estruturas impessoais devem-se levar em conta dois fenômenos:

I. A posição de sujeito é o alvo imediato das operações que alteram a diátese: verbo-passivização pessoal e impessoal, causativização, ergativização. Assim, salvo especificação em contrário, são externos todos os argumentos ou papeis temáticos que são apagados ou acrescentados por uma operação.

II. No PB deve-se considerar a possibilidade de reinterpretação do SN-sujeito designativo de lugar/tempo como um locativo que se realiza perifericamente como um sintagma preposicionado adjunto, exemplo (135).

Com relação a que caso atribuir para este argumento, Franchi et alii (1998), afirmam que o único argumento da sentença é um argumento interno e recebe caso acusativo. Eles apresentam duas argumentações para isso: 
I. A dematização da posição de argumento externo não exclui, no caso das CEs do PB, outras estratégias de indeterminação do sujeito. Com relação ao esvaziamento semântico do sujeito, isso se faz mediante outro mecanismo sintático: a presença de um sujeito indeterminado - como você, a gente - em contextos bem claros que excluem uma interpretação predicativa.

137. Em relação à idade média, você tinha honrarias concedidas a duques. ${ }^{41}$

Se há um preenchimento com um sujeito indeterminado, então o SN pós-posto deve mesmo ser um argumento interno no PB.

II. Possibilidade do clítico SE marcando justamente a supressão do argumento externo com a indeterminação do sujeito:

138. Se poderia ter uma religião que trabalhasse 8 horas por dia e pronto.

Franchi et alii (1998) ainda dizem que esses exemplos (137) e (138) mostram que o verbo TER tem guardado na sua memória lexical, sua estrutura cheia ${ }^{42}$.

Retomando alguns pontos colocados no artigo analisado de Franchi et alii (1998), vimos que o sentido de um item lexical deve ser determinado através de uma relação de sentidos que se estabelece entre expressões lingüísticas e que são determinadas pelas propriedades semânticas dos próprios itens lexicais. Ou seja, a análise semântica da sentença depende de sua própria composição, que, depois de construída uma expressão

\footnotetext{
${ }^{41}$ Exemplos (137) e (138) retirados de Franchi et alii (1998).

${ }^{42}$ Por isso, alguns lingüistas preferem postular a existência de um expletivo nulo, que não seria nem o locativo, nem o SN argumento. Nesta dissertação, não entrarei no mérito desta proposta. Basta dizer que para alcançar uma estrutura mais enxuta, não preciso postular a existência de um expletivo.
} 
complexa, com seus itens léxicos relacionados, faz com que um sentido determinado seja expresso.

Para Franchi et alii (1998), as CEs fazem parte de um grupo maior chamado de “construções impessoais", pois tem as seguintes características:

i. O complemento externo selecionado por esses verbos pode ser inanimado, designativo de lugar/tempo ou um sintagma que pode ser interpretado como local/tempo.

ii. Esse argumento é interpretado como locativo e aparece em posição periférica.

Observemos o exemplo abaixo:

139. Naquela bolsa tem uma carteira com meu cartão, pode usar a vontade.

140. Tem uma carteira com meu cartão naquela bolsa, pode usar a vontade.

Em (139) e (140), vemos que naquela bolsa é um sintagma inanimado, designativo de lugar e aparece em posição periférica, antes ou depois do verbo, mostrando que TER não tem um papel temático para atribuir à posição de sujeito da sentença.

A seguir vamos ver a proposta de Pustejovsky para o léxico e a proposta de Viotti para as CEs do PB. 


\subsection{A teoria do léxico gerativo de Pustejovsky (1998)}

Pustejovsky propõe a teoria do léxico gerativo com o objetivo de criar um modelo no qual o léxico tenha uma capacidade gerativa. Ou seja, para o autor, o léxico não é estático como uma lista de signos lingüísticos enumerados em um dicionário, mas um nível organizado de acordo com uma teoria mais rica e cheia de recursos de construção e desconstrução do significado das palavras.

Desta forma, ele pretende explicar o uso criativo das palavras, como o signo lingüístico pode ter significados diferentes dependendo do contexto, sem se contentar com explicações não muito científicas como o "saber enciclopédico" ou o "conhecimento de mundo". Além disso, pretende dar conta também de problemas de relação entre o léxico e a sintaxe, como a estrutura de evento e a estrutura sintática, por exemplo.

Um dos conceitos básicos da teoria de Pustejovsky é o da subespecificação. A subespecificação é nada mais do que a não especificação dos signos lingüísticos que os capacita a intervir em diferentes estruturas sintáticas e, como conseqüência, em distintas operações de composição semântica. Observemos os exemplos a seguir:

141. João comprou a novela.

142. João começou a novela.

143. João terminou a novela.

Uma palavra como novela, por exemplo, pode adquirir sentidos diferentes em contextos diferentes. Em (141), entende-se novela como uma entidade física passível de ser comprada. Em (142), João pode ter começado a ler a novela, ou pode ter começado 
a escrever a novela. O mesmo ocorre em (143), João pode ter terminado de ler a novela ou terminado de escrever a novela.

O tipo de informação que um signo lexical como novela pode vir a significar está contida no que Pustejovsky chama de Estrutura Qualia. É na Estrutura Qualia que a estrutura argumental e a estrutura eventual se encontram para aplicar os mecanismos gerativos do léxico e gerar as mudanças semânticas necessárias. Ela é composta de quatro tipos de característica que os signos apresentam:

i. Quale constitutivo: que codifica a relação entre o objeto e as partes que o constituem. São informações do tipo físico (material, peso, partes e elementos componentes).

ii. Quale formal: que codifica aquilo que diferencia o objeto dentro de um domínio mais amplo. São informações sobre a orientação, magnitude, forma, dimensão, cor, posição.

iii. Quale télico: codifica o propósito e a função desse objeto.

iv. Quale agentivo: codifica fatores implicados na origem ou produção de um objeto. São informações sobre o criador, o artefato, a classe natural ou a cadeia casual que gerou sua existência.

Juntamente com sua estrutura qualia, o léxico também fornece informação sobre a estrutura argumental e a estrutura eventiva de uma determinada entrada. A estrutura argumental fornece dados como o número e o tipo de argumentos que o item lexical pede e ainda como eles se realizam sintaticamente. A estrutura eventiva indica o tipo de evento denotado por um determinado item lexical. 
Para Pustejovsky, os eventos são dotados de uma estrutura interna e podem se decompor em diferentes sub-eventos. Os eventos podem denotar: estados, processo ou transição ${ }^{43}$.

Assim, a estrutura de uma palavra como novela seria a seguinte:

$$
\begin{gathered}
\text { novela } \\
\text { estrutura argumental }=\arg 1=y \text { : informação } \\
\arg 2=\mathrm{x} \text { : objeto físico } \\
\text { Qualia }=\text { Constitutivo }=\operatorname{narrar}(\mathrm{y}) \\
\text { Formal }=\text { livro }(\mathrm{x}, \mathrm{y}) \\
\text { Télico }=\text { ler }\left(\mathrm{e}^{44}, \mathrm{w}, \mathrm{x}, \mathrm{y}\right) \\
\text { Agentivo }=\operatorname{escrever}\left(\mathrm{e}^{45}, \mathrm{v}, \mathrm{x} . \mathrm{y}\right)
\end{gathered}
$$

Dessa forma, Pustejovsky quer dar conta, de modo mais econômico, da polissemia e da ambigüidade das palavras nas línguas naturais. Sem a Estrutura Qualia, teríamos, pelo menos, quatro entradas diferentes para a palavra novela; com a Estrutura Qualia temos apenas uma entrada que pode assumir diferentes significados.

Com este modelo, o autor que propõe que as entradas lexicais são subespecificadas, capazes de assumir, dependendo do contexto, o quale mais adequado. Dessa forma, se pode explicar como palavras ou expressões podem ampliar seu significado, se distanciando do original ou literal, e, ainda assim, serem compreendidas pelos falantes da língua.

\footnotetext{
${ }^{43}$ Veremos mais detalhes sobre os sub-eventos ao estudar a proposta de Viotti (1999) para as construções com TER.

${ }^{44} \mathrm{e}=$ evento

${ }^{45}$ Idem 38
} 
Para garantir que as "novas" expressões formadas estejam boas, ou seja, não sejam agramaticais, a Teoria do Léxico Gerativo vai estabelecer um conjunto de princípios que controlam a formação da sentença e captam a relação semântica entre as unidades que a compõe:

i. Type Coercion: quando um determinado sintagma de uma sentença se vê coagido a "assumir" uma determinada interpretação por outro elemento da mesma sentença, sem alterar sua estrutura sintática. Por exemplo: novela é um objeto físico, mas em (142) é coagido por começar a se tornar um evento.

ii. Selective Binding: quando um elemento léxico ou um sintagma opera sobre a subestrutura, sem alterar o tipo geral da sentença. Por exemplo, casos em que o verbo subir permite obter duas interpretações, uma causativa (145) e outra inacusativa (146).

145. O governo subiu o preço da gasolina

146. O preço da gasolina subiu.

iii. Co-composition: ocorre quando vários elementos lexicais se unem, para gerar novos sentidos não lexicalizados, em uma sentença.

147. Fazer um peixe no forno.

148. Fazer um bolo no forno. 
Em (147), o peixe é uma entidade preexistente que somente será assada no forno, mas em (148), o bolo não existia antes de se feito no forno, o bolo será criado pela ação de assar do forno.

Para Pustejovsky, a informação contida em uma determinada estrutura age através desses princípios e mecanismos e essa ação é essencial para interpretar as palavras inseridas em um determinado contexto e para entender certos processos sintáticos que ocorrem. 


\subsection{A proposta de Viotti (1999)}

Tendo esse tipo de relação em mente, vamos ver como Evani Viotti trabalha este conceito com as CEs do PB com o verbo TER.

Para Viotti existem algumas questões sobre o verbo TER que devem ser respondidas:

a. TER é uma unidade lexical, ou é o resultado de uma composição sintática?

b. TER é uma categoria lexical de natureza verbal, que apresenta uma grade temática e atribui papeis temáticos, ou é uma categoria funcional?

c. Será um mesmo verbo TER que constrói o mesmo significado das sentenças, ou será que o léxico tem diferentes entradas para TER? Isto é, haveria diferentes verbos TER?

d. Qual é a sintaxe dos vários tipos de sentenças construídas com TER? É a mesma estrutura ou são estruturas diferentes?

Quando estamos estudando as CEs do PB, o comportamento do verbo TER é o que mais intriga. Como podemos tratar esses "variados" TER? Como seria a questão da entrada de léxico do TER tratado deste modo? Teríamos entradas diferentes quando o TER tivesse seu sentido pleno de "posse"? O verbo TER vem se esvaziando desde o latim (assim como ocorreu com HAVER) podendo hoje ser considerado como um verbo leve $e^{46}$

Observemos as sentenças a seguir:

\footnotetext{
${ }^{46}$ Verbo Leve é um verbo que se esvaziou sintática e semanticamente e que passou a ser aplicado de forma diferente que originalmente. Nesse sentido, HAVER seria um verbo leve porque de seu significado original de posse, com uma estrutura lexical de 2 argumentos, passa a ser impessoal, significando existência. Para Viotti, TER é um primitivo lexical esvaziado de conteúdo semântico. Desta forma não atribui papéis temáticos, pois só os verbos de conteúdo pleno podem atribuir papéis temáticos.
} 
149. A Joana tem um carrinho novo em folha. (posse alienável)

150. Pedro tem o cabelo castanho escuro. (posse inalienável)

151. Paulo tinha dores de cabeça terríveis. (experiência)

152. Aquela caixa tem todos os documentos da casa. (locação)

153. Susana gosta de ter os filhos sempre debaixo de suas asas. (controle do sujeito)

154. Júlia tem participado de todos os congressos. (verbo auxiliar formador de perífrase)

155. Tinha muita gente na festa. (sentença existencial)

O verbo TER aparece em uma variedade de sentenças porque é um verbo leve, esvaziado de conteúdo semântico, não atribuindo papel temático, e por isso não tem capacidade predicativa.

Para a autora, é importante tratar o verbo TER como uma entidade lexical única, ou seja, independente do tipo de construção que ele forma ou da natureza de seus complementos, há apenas uma entrada lexical para TER. Desta forma, haverá apenas uma abordagem para a análise das sentenças formadas.

Então, se TER é vazio de significado, como se daria a atribuição de sentidos nas sentenças com TER? As relações de sentido de uma sentença são, na verdade, resultado da composição das denotações e dos sentidos de todas as expressões lingüísticas que compõem a sentença.

Para Viotti, seguindo Franchi, um par de objetos sintáticos podem se relacionar para criar um objeto sintático complexo que por sua vez pode se unir a outros objetos sintáticos, criando objetos sintáticos ainda mais complexos. A combinação de objetos 
sintáticos que constroem objetos sintáticos complexos é chamada por Franchi de predicação $^{47}$.

Nos exemplos abaixo, vemos como a interpretação de uma sentença depende de uma análise composicional do conteúdo semântico dos itens lexicais que constituem a sentença.

156. (a) O menino quebrou o vaso.

(b) O menino quebrou o braço.

Em (156a), menino pode ser interpretado como um Agente, enquanto dificilmente em (156b) teríamos outra leitura que não fosse a de Experienciador.

Assim sendo, segundo Viotti, tanto o processo interpretativo, quanto a realização sintática de algumas expressões, são fruto não só das propriedades sintáticas e semânticas dos itens lexicais, mas também do resultado da composição desses itens lexicais em objetos sintáticos e semânticos complexos.

No caso das sentenças construídas com verbos leves, como TER, fica mais claro entender como o principio da composicionalidade atua, principalmente quando levamos em consideração que todos os elementos lexicais de uma sentença complexa influenciam na interpretação dessa expressão, inclusive adjuntos, que muitas vezes são considerados opcionais.

157. A Maria tinha muitas jóias.

158. A Maria tinha muitas jóias guardadas debaixo do colchão.

\footnotetext{
${ }^{47}$ Para Franchi, segundo Viotti, a predicação é uma relação de sentido que se estabelece entre expressões linguisticas significando que a relação de predicação é determinada exclusivamente pelas propriedades semanticas dos itens lexicais. A Predicação ocorre sempre que um par de expressões sintáticammente compatíveis forem combinadas. Para ele a Predicação deve estar envolvida em todas as combinaçoes de quaisquer categorias substantivas (Nome, Verbo, Adjetivo, Adverbio, Preposição).
} 
159. A Maria tinha muitas jóias da Regina guardadas debaixo do colchão.

160. A Maria teve muitas jóias destruídas pelo fogo.

Ou ainda:

161. A minha colega tinha muitos livros de política e lingüística.

162. Aquela editora tem muitos livros de política e lingüística.

163. O Chomsky tem muitos livros de política e lingüística.

164. Aquela caixa tem muitos livros de política e lingüística.

Como podemos, ver a alteração de um item lexical altera também o sentido da sentença. Viotti mostra, através dos exemplos anteriores, que TER não pode restringir sua classificação dentro de um sistema rígido de determinados paradigmas e que, além disso, há como explicar a multiplicidade de interpretações através da combinação dos sentidos individuais dos itens lexicais.

Como vimos nos exemplos (149) a (155), o verbo TER não tem restrições quanto aos seus argumentos. Dentre todos os tipos de construções que esse verbo pode participar, as que resultam mais importantes para o trabalho de Viotti, e consequentemente, para este estudo são as construções em que o sujeito do verbo TER vai poder ser interpretado como expressões de tempo ou lugar:

165. (a) Aquela rua de Chicago tem várias estátuas de artistas famosos.

(b) Tem várias estátuas de artistas famosos naquela rua de Chicago.

166. (a) A festa tinha muita gente.

(b) Tinha muita gente na festa. 
Juntamente com Franchi e Negrão (1998), Viotti chega a conclusão que as CEs do PB estão contidas em um grupo maior: as "construções impessoais". Afinal, o argumento externo pode ser inanimado, pode designar lugar ou tempo e, também, pode ser um sintagma que poderá ser interpretado como lugar/tempo. Além disso, esse argumento é interpretado como um locativo e aparece em posição periférica na sentença.

O diferencial do verbo TER é que ele pode designar argumentos externos que, apesar de não serem primeiriamente argumentos locativos, acabam se passando por um:

167. Las Vegas tem muitas luzes.

168. O queixo daquele homem tem um furinho engraçado.

Tanto Pustejovsky quanto Franchi trabalham com a noção de composicionalidade para dar conta de um uso variado de um mesmo léxico. Os dois autores também consideram todas as categorias sintáticas substantivas como possíveis de serem predicadores. Para Pustejovsky a lista de papeis temáticos é insuficiente para dar conta da interpretação semântica da sentença, por isso deve-se desenvolver um método formal de decomposição lexical para resolver questões cuja solução se dá com a teoria de papeis temáticos. Para Franchi, a lista também é insuficiente, mas os papeis temáticos são nada mais que o resultado da Predicação.

Pustejovsky divide o léxico em níveis e Viotti considera esses níveis como sendo relevantes para o estudo do léxico das CEs: 


\begin{tabular}{|l|l|}
\hline Estrutura argumental & número de argumentos lógicos \\
\hline Estrutura de evento & tipo de evento gerado \\
\hline Estrutura qualia & $\begin{array}{l}\text { representação altamente estruturada dos fatores que nos levam } \\
\text { a compreensão dos itens lexicais, sobre a qual podem se dar } \\
\text { transformações semânticas que alteram a denotação dessa } \\
\text { palavra quando ela entra em composição com outras palavras } \\
\text { ou outros sintagmas. }\end{array}$ \\
\hline
\end{tabular}

Viotti segue a proposta de Pustejovsky para a análise do léxico e encontra a seguinte análise para seus dados:

\section{Estrutura de evento}

Para Viotti a divisão da estrutura de evento em sub-estruturas, como Pustejovsky propõe, e a relação entre elas, pode explicar algumas peculiaridades das construções existenciais no português. Apesar de ser um verbo leve, TER ainda mantém a estrutura sintático-argumental de um verbo transitivo com espaço para dois argumentos, como em (169):

169. Maria tinha uma caneta.

170. Tinha uma caneta na bolsa da Maria

Nesse exemplo, TER tem um argumento externo, Maria, e um argumento interno, uma caneta. Ao contrário de (170), no qual TER tem apenas o argumento interno: uma caneta.

Então, TER ainda preservaria uma estrutura que apresenta dois sub-eventos, sendo que cada um desses sub-eventos estaria atrelado a um argumento de TER. 
Entretanto, tanto seus argumentos quanto seus sub-eventos seriam sub-especificados, de modo que só podemos conceber o tipo à medida que os itens lexicais vão se combinando. Ou seja, só é definido o tipo de predicação de TER (posse ou existência) na combinação dos seus itens lexicais. Por isso, é possível uma grande variedade de construções que podem ser realizadas com o mesmo verbo como podemos ver repetidas a seguir:

171. A Joana tem um carrinho novo em folha. (posse alienável)

172. Pedro tem o cabelo castanho escuro. (posse inalienável)

173. Paulo tinha dores de cabeça terríveis. (experiência)

174. Aquela caixa tem todos os documentos da casa. (locação)

175. Susana gosta de ter os filhos sempre debaixo de suas asas. (controle do sujeito)

176. Júlia tem participado de todos os congressos. (verbo auxiliar formador de perífrase)

177. Tinha muita gente na festa. (sentença existencial)

\section{Estrutura Qualia}

É nessa estrutura que está expressa a relação que existe entre os argumentos e seus sub-eventos. E é por meio dessa relação que é definido o conteúdo semântico de um predicado. Quando estamos falando do verbo TER, temos que entender que toda a estrutura é sub-especificada, somente sendo interpretada na relação com as Estruturas Qualia dos sintagmas nominais com ele combinados. Como vimos na seção anterior, são quatro os tipos de relação que podem existir entre os argumentos e seus subeventos: 
a. Quale constitutivo: relação entre o objeto e seus constituintes

b. Quale formal: distingue o objeto dentro de um domínio mais amplo

c. Quale télico: estabelece a função ou objetivo deste objeto

d. Quale agentivo: fatores envolvidos na origem deste objeto.

Dessa forma, o modelo do léxico gerativo da conta da polissemia das sentenças construídas com o verbo TER, segundo as características que os elementos combinados apresentam relativamente a essas três estruturas (argumental, de evento e qualia)

Vejamos a sentença a seguir: ${ }^{48}$

178. Aquela editora tem muitos livros de política e de lingüística.

Em (178) temos uma estrutura argumental com dois argumentos, um externo, que é o sujeito: aquela editora, e outro interno, muitos livros de política e de lingüística. Cada um desses argumentos tem uma Estrutura Qualia. O argumento externo é o local físico que contém a organização ou finalidade da organização (publicar livros). O argumento interno é o objeto físico que contém a informação ou informação destinada à leitura que tem origem no ato de publicar o livro. Também há a estrutura de evento, aqui cada argumento está vinculado a um sub-evento, esses sub-eventos são subespecificados, não há como saber, antecipadamente, se são processo, transição ou estado. Eles serão definidos somente na composição da sentença.

Como resultado temos:

A. Estrutura Qualia:

i. Conexão física: posse (quale constitutivo)

\footnotetext{
${ }^{48}$ Exemplo retirados de Viotti (1999)
} 
A editora estoca os livros que publica ou muitos livros de política e de lingüística se localizam ou fazem parte do acervo de livros publicados pela editora.

ii. Publicar: (quale télico + quale agentivo)

B. Estrutura de evento:

i. Publicar:

$1^{\circ}$. Sub-evento (quale agentivo) - processo

$2^{\circ}$. Sub-evento (quale formal) - estado resultante.

ii. Posse: os dois sub-eventos são interpretados como estado simultaneamente, ou seja, a editora publicou o livro e a editora possui o livro.

Viotti ainda mostra que é na escolha de qual sub-evento que será marcado como núcleo que temos dois tipos de construções com o verbo TER: as construções de posse e as construções existenciais. Se marcarmos o $2^{\circ}$. sub-evento como núcleo, temos uma CEs, mas se o $1^{\circ}$. sub-evento for marcado como núcleo a construção é o tipo possessiva. Observemos os exemplos de sentenças possessivas (179) e existenciais (180) a seguir:

179. Aquela editora tem muitos livros de política e de lingüística. ( $1^{\circ}$. subevento marcado como núcleo).

180. Tem muitos livros de política e de lingüística naquela editora. ( $2^{\circ}$. subevento marcado como núcleo). 
Deste modo, Viotti espera dar conta da formação das CEs com o verbo TER no PB. Além disso, ela também esclarece como sentenças com significados semânticos tão próximos quanto (179) e (180) podem ter uma estrutura sintática distinta. Vejamos os exemplos repetidos a seguir:

181. [[Aquela editora] [tem [muitos livros de política e de lingüística]]]. ( ${ }^{\circ}$. sub-evento marcado como núcleo - TER possessivo).

182. [Tem [[muitos livros de política e de lingüística] [naquela editora]]]. ( $2^{\circ}$. Sub-evento marcado como núcleo - CEs).

Para a Viotti, é possível tratar TER como uma entidade lexical única, ou seja, quer ele seja existencial, quer ele seja possessivo, quer seja auxiliar ou que ele seja modal, existe apenas uma entrada lexical para todos. Isso é somente possível porque TER é um verbo leve, semanticamente vazio, incapaz de determinar as relações predicativas, podendo ser preenchido com uma série de complementos. Assim, a função do verbo TER seria ligar seus argumentos, funcionando como um verbo de ligação.

Como as especificações temáticas não são determinadas exclusivamente pelo verbo, a questão que está sendo examinada é: como se dá a atribuição do papel temático? Entendendo essa relação poderemos responder às seguintes questões:

I. Por que TER não permite a combinação de todo e qualquer tipo de argumento?

183. Juliana tem dinheiro.

184. *A mesa tem dinheiro. 
II. Por que é que algumas sentenças com TER permitem a promoção de argumentos a algumas posições e outras não?

185. O restaurante tem estacionamento.

186. Tem estacionamento no restaurante.

187. A mesa tem uma perna de metal.

188. *Tem uma perna de metal na mesa.

III. Se TER é parecido com SER/ESTAR em seu esvaziamento, como eles não significam a mesma coisa?

189. O Chico é um advogado famoso.

190. O Chico tem um advogado famoso.

A partir desses exemplos, Viotti aprofunda sua posição sobre o caráter genérico da relação do verbo TER, mais especificamente com relação ao TER existencial. Para ela, através do principio de composicionalidade, podem-se gerar novos sentidos léxicos não previstos anteriormente, para as palavras participantes da composição através da combinação de sintagmas. A autora fala, seguindo Pustejovsky, de três tipos de níveis que representam a composicionalidade de um léxico. Vamos relembrar:

A. Estrutura argumental - que define o número de espaços argumentais que um léxico pode abrir.

B. Estrutura de evento - que define os tipos de eventos normalmente relacionados a este léxico. 
C. Estrutura Qualia - que engloba um conjunto de propriedades ou eventos associados a um item lexical, que explicam seu significado.

Quando se trata do verbo TER, Viotti defende que apesar de ter uma representação lexical completa, ela é subespecificada. Deste modo, ao ser combinado com outros itens lexicais, sua estrutura quale é preenchida, influenciada pela representação lexical dos argumentos, e se dá origem a novos sentidos.

Sendo assim, o papel temático também deve ser atribuído através da composicionalidade das sentenças. Se em (183) a sentença está boa é porque o resultado da composicionalidade de Juliana com dinheiro é boa, ou seja, dinheiro pode predicar de Juliana. Mas se em (184), a sentença é estranha é porque o resultado da composicionalidade é ruim, ou seja, dinheiro também não predica de mesa.

Uma estrutura com o verbo TER não tem o evento marcado, por isso falamos de sub-eventos, essa sub-especificação pode gerar várias interpretações e seu significado dependerá de qual sub-evento será marcado:

191. Aquele baú tem roupas para serem doadas.

192. Tem roupas para serem doadas naquele baú.

Quando temos uma estrutura como em (191), significa que o argumento externo do verbo, aquele baú, unido ao sub-evento gerado por TER, é realizado na posição de sujeito, mostrando que o sub-evento de posse foi marcado como núcleo do evento. Ou seja, o sub-evento de posse é o mais importante da estrutura, gerando uma sentença onde TER tem um sujeito e um objeto, como corresponde à estrutura argumental em que há um possuidor e algo possuído. 
Já em (192), o argumento externo não é um sujeito, mas uma expressão locativa: naquele baú. Então, o sub-evento gerado por TER não está unido ao núcleo que foi marcado como mais importante da sentença, sendo desta forma realizado como um adjunto e não como um argumento. O que resulta numa possibilidade de nova de interpretação do significado do verbo, gerando uma $\mathrm{CE}$, com a interpretação de uma sentença apresentacional.

Desta forma podemos tratar o verbo TER de forma homogênea, sem precisar recorrer a várias entradas lexicais para sentenças com significados tão parecidos como (191) e (192).

Outro problema quando se estuda as CEs é a atribuição de Caso. Viotti crê que nenhuma das propostas existentes explica a atribuição de Caso nos sintagmas nominais das CEs. Para ela, Se há apenas uma entrada lexical para TER, então, mesmo em CEs esse verbo deve carregar traços de Caso acusativo e deve entrar em uma relação de checagem com um sintagma nominal.

Desta forma, não seria necessária a postulação de mais de um verbo TER, o que iria contra a tentativa anterior quando se tratou da questão da entrada lexical, ou seja, mesmo sendo TER possessivo ou existencial, o caso que deve ser atribuído ao sintagma nominal pós-verbal é o acusativo.

Assim, não é preciso trabalhar com propostas baseadas no efeito de definitude para atribuir caso aos argumentos gerados por TER (que sempre devem buscar alternativas quando o efeito de definitude não se aplica). A proposta de efeito de definitude se baseia em casos de línguas, como o Finlandês, que dependendo da definitude do sintagma nominal pós-verbal pode haver uma alteração no caso que será atribuído. Mas no caso do português do Brasil, como explica Viotti, podemos realizar 
CEs definidas (81) e (194) e indefinidas (195) e (196), então não há como recorrer à definitude para poder atribuir o Caso.

193. Há o João, supervisor, que pode levar a classe para o passeio.

194. Tem o João, supervisor, que pode levar a classe para o passeio.

195. Há um homem na sala esperando por você.

196. Tem um homem na sala esperando por você.

A questão da atribuição de Caso acusativo não é um ponto de acordo entre os lingüistas, neste trabalho não pretendo entrar a fundo nessa questão, pois envolveria outros estudos e o assunto se estenderia além do que se propõe essa humilde dissertação.

Agora, nos interessa analisar os dados do português e do espanhol arcaicos e estudar como se comporta o verbo TENER diante dos trabalhos que até aqui foram expostos. 


\subsection{Uma proposta de análise para os verbos do português arcaico}

Aqui, apresentarei algumas idéias para a análise do português arcaico. Para tanto, vou me basear nos autores até aqui estudados: Franchi et alii (1998), Viotti e Pustejovsky. Apesar de não tratarem diretamente com esses dados, suas propostas podem ajudar a entender melhor o desenvolvimento desses verbos.

Como que a teoria de subespecificação de léxico pode nos ajudar a entender as mudanças ocorridas com TER e HAVER?

Observemos as sentenças com AVER e TEER a seguir:

197. (h)aver pan, remedio, horto, bispado, logares, morada, casa, ovelhas

198. (h)aver fe, graça, poder, poderio, medo, voontade, avondança, door

199. (h)aver barvas, ceguidade, cinquenta anos, enfermidade.

200. teer cireos, espada, cavalo, candea, meezinha, arca, logares, caneiro ${ }^{49}$

Esses exemplos são datados dos séculos XIV e XV. Apesar de terem campos semânticos similares, TEER e AVER a principio não se comutavam. AVER era usado para coisas mais abstratas e TEER para algo mais concreto. Primeiramente não haveria porque o léxico de TEER e AVER ser sub-especificado. Existia apenas uma interpretação para cada sentença, qualquer um dos dois verbos significava posse. A única diferença entre cada um desses verbos é que TEER indicava posse de coisas mais concretas e AVER indicava posse de coisas mais abstratas. Com os campos semânticos divididos desta forma, não há porque postular uma sub-especificação de seu evento.

\footnotetext{
${ }^{49}$ Exemplos de 198 a 201 retirados de Mattos e Silva (1994).
} 
Entretanto, entre os séculos XV e XVI, HAVER e TER passam a ser usados como sinônimos, ou seja, TER não mais restringe sua 'posse' a coisas concretas, mas também passa a indicar 'posse' de coisas abstratas, ou seja, ele perde o sentido mais específico de "ter na mão", "segurar":

201. haver/ter cousas; haver/ter paz; haver/ter oolhos

Assim, os limites semânticos de cada verbo começam a se misturar.

Conforme HAVER vai se esvaziando de seu significado de posse, TER expandindo sua grade temática. No exemplo (202), vemos HAVER ser usado como verbo auxiliar e também mantendo seu significado de possessivo presente.

202. E non sabedes quanto afam e trabalho avedes tomado e quantas espadadas e seetadas havedes levadas. avedes tomado - HAVER como verbo auxiliar havedes levadas - HAVER como verbo pleno, indicando posse.

A partir daí é interessante pensar em HAVER como sendo sub-especificado, ou seja, se há concordância no particípio então HAVER será interpretado como verbo possessivo. Se o particípio não apresentar marca de número ou pessoa HAVER será interpretado como um verbo auxiliar.

Como vimos nos capítulos anteriores, outro uso de HAVER documentado no português arcaico é o existencial ou impessoal:

203. Non avia padres santos. 
Como o HAVER 'possessivo', o HAVER 'auxiliar' e o HAVER 'existencial/impessoal' coexistiam, o único modo de diferenciar o primeiro do último era através das marcas de pessoa e de número. Se HAVER não mostra concordância com o argumento ligado a ele então ele deve ser um impessoal.

Com essa breve exposição quero mostrar que HAVER no português arcaico deveria ter seu léxico sub-especificado, o tipo de HAVER utilizado só é definido depois de compostas todas as expressões sintáticas da sentença. No PB atual a mesma coisa ocorre para TER. Ou seja, enquanto HAVER vai se esvaziando e deixando de ocupar certos "lugares" lexicais, TER vai ampliando sua grade temática e "seguindo" HAVER. 


\subsection{Conclusões}

Neste capítulo, quis mostrar duas análises muito semelhantes para a situação das CEs com TER no PB.

Evani Viotti, seguindo Pustejovsky, vê TER como o resultado de uma composição de outros itens de uma sentença que irá interpretar este verbo como TER 'possessivo' ou como TER 'impessoal'.

Para Franchi et alii (1998), o sentido de um item lexical deve ser determinado através da relação dos sentidos de todos os itens que compõem aquela expressão lingüística. TER deve ser visto como um operador funcional, um verbo leve. $\mathrm{O}$ verbo deve, nesse caso, simplesmente indicar uma relação entre os outros elementos da coda, expressando o tempo e o aspecto da sentença, mas não atribuindo qualquer papel sintático ou semântico aos elementos da coda.

A seguir, tentei demonstrar, com alguns exemplos do português arcaico, que HAVER passou pelos mesmos estágios que TER passa hoje. Com isso não quero afirmar ou sugerir que TER seguirá os mesmos passos de HAVER, ou que HAVER está condenado ao desaparecimento, mas quero apenas destacar que, pelo menos para os dados do português, arcaico e atual, as análises apresentadas aqui parecem ser satisfatórias. 
CAPÍTULO 5 
5. Uma análise do verbo TENER à luz do confronto com o verbo TER.

Primeiro farei uma pequena introdução sobre o comportamento das construções com o verbo TENER e as CEs com HABER no espanhol. Depois apresentarei brevemente as propostas existentes para o estudo do léxico e das relações léxicosintaxe-semântica, para, por fim, analisar as construções com o verbo TENER. 


\subsection{Introdução}

A seguir, vamos fazer uma comparação entre as construções com TER e com TENER:

204. a. A Joana tem um carrinho novo em folha. (posse alienável)

b. Juana tiene un coche nuevo.

205. a. Pedro tem o cabelo castanho escuro. (posse inalienável)

b. Pedro tiene una/la nariz larga.

206. a.Paulo tinha dores de cabeça terríveis. (experiência)

b. Pablo tiene miedo de la oscuridad.

207. a. Aquela caixa tem todos os documentos da casa. (locação)

b. Aquella casa tiene tres cuartos.

208. a. Susana gosta de ter os filhos sempre debaixo de suas asas. (controle do sujeito)

b. A Juan le gusta tener a todos bajo su control.

209. a. Júlia tem participado de todos os congressos. (verbo auxiliar)

b. *Julia tiene participado de todos los congresos.

c. Julia tiene leídas todas las novelas.

210. a. Tinha muita gente na festa. (sentença existencial)

b. *Tenía mucha gente en la fiesta.

Como vimos, TENER não é tão leve quanto TER, mas podemos dizer que é um verbo pleno? Como verbo pleno, seu sentido também se dá através da composicionalidade? 
Observando estes exemplos, notamos que o verbo TENER no espanhol se comporta de modo diferente de TER no português.

Mesmo com estas diferenças é possível analisar as construções com TENER através do processo de composicionalidade? Será que através desta análise vamos entender a diferença estrutural existente entre TER e TENER?

Como já foi dito, o principio de composicionalidade da análise semântica de uma sentença se dá depois de construída uma expressão complexa, com seus itens léxicos relacionados. No caso de TER, pudemos dizer que ele é um verbo sub-especificado. Mas quando estamos falando de TENER não existe a possibilidade de (212):

211. La casa tiene quatro quartos - verbo pleno.

212. *En la casa tiene quatro cuartos. - verbo leve.

Vemos, então que TENER não é um verbo tão leve no espanhol, mas mesmo assim, há sentido em falar de composicionalidade se o verbo vai ser pleno? A princípio sim, a composicionalidade nos ajuda a interpretar todos os outros sentidos de TENER:

213. Juana tiene un coche nuevo. (posse alienável)

214. Pedro tiene una/la nariz larga. (posse inalienável)

215. Pablo tiene miedo de la oscuridad. (experiência)

216. Aquella casa tiene tres cuartos. (locação)

217. A Juan le gusta tener a todos bajo su control. (controle do sujeito)

218. Julia tiene leídas todas las novelas. (predicativo do objeto) 
Vejamos os seguintes exemplos do PB para depois compará-los com os do espanhol:

219. (a) O menino quebrou o vaso. - o menino = agente

(b) $\mathrm{O}$ menino quebrou o braço. - o menino $=$ Experienciador

Através do principio de composicionalidade podemos ver como muda a interpretação de uma sentença caso haja mudança de um item lexical. Como vimos no capítulo anterior, segundo Viotti, tanto o processo interpretativo, quanto a realização sintática de algumas expressões são o fruto não só das propriedades sintáticas e semânticas dos itens lexicais, mas também do resultado da composição desses itens lexicais em objetos sintáticos e semânticos complexos.

Quando olhamos para a construção dessas sentenças no espanhol, percebemos que para que haja a mesma interpretação de acidente que existe em (b) devemos usar uma estrutura gramatical diferente. $\mathrm{O}$ que antes era Agente passa a ser Experimentador.

Podemos entender que o processo de composicionalidade interfere até na estrutura gramatical da sentença? $\mathrm{Na}$ verdade, em minha opinião ocorre o contrário. Todo o processo de composicionalidade está alicerçado nos itens lexicais que formam a expressão gramatical. Ou seja, uma vez que uma expressão esteja formada na sintaxe, esse princípio entra em ação para que haja uma interpretação da sentença.

Essa é uma questão interessante para quem trabalha na interface léxico-sintaxe. Como que as unidades léxicas se projetam na sintaxe? O significado e o que pode vir significar uma palavra já estão no léxico ou isso é dado através da interpretação do contexto em que a expressão sintática foi realizada?

Na próxima seção apresento algumas propostas para tratar desse assunto. 



\subsection{Teorias, modelos e hipóteses para trabalhar o léxico segundo}

Mendikoetxea (2004).

Segundo Mendikoetxea (2004), qualquer modelo ou teoria léxica deve abarcar três componentes básicos:

i. uma lista de primitivos léxicos;

ii. um conjunto de regras ou princípios de formação de estruturas léxicas;

iii. um conjunto de regras ou mecanismos de enlace ou projeção na sintaxe.

Seguindo esses pré-requisitos, há duas importantes linhas de pesquisa sobre essa questão: os modelos projecionistas e os modelos (neo)construtivistas.

Para os modelos projecionistas, os verbos aparecem listados no léxico com uma representação léxico semântica de seu significado que se projeta na estrutura sintática. A idéia é que a entrada lexical contém todas as informações necessárias para determinar as propriedades léxicas. Esse modelo se baseia no Principio de Projeção de Chomsky (1981).

Para os modelos (neo)construtivistas a projeção de um argumento de um predicador não vem determinada desde o léxico. O que determina quantos e que tipos de argumentos devem existir é a própria construção sintática. Os argumentos se projetam livremente na sintaxe e a interpretação é uma combinação do significado do predicador com a estrutura sintática resultante.

Para o modelo projecionista a principal questão é: que tipo de representação léxico-semantica é a mais adequada? Há propostas para essa representação: 
i. listas não estruturadas de papéis semânticos;

ii. os proto-roles de Dowty (1991) ou

iii. decomposição de predicados

A representação de léxico através de uma listas de papéis temáticos segue o modelo de entradas léxicas em Chomsky (1981). Um léxico qualquer teria seus argumentos e papéis temáticos definidos no léxico, dessa forma o conjunto lexical de uma língua seria como um saber enciclopédico.

$$
\begin{aligned}
& \text { 220. beber - VERBO - \{agente, tema }\}-[\text { _ }(\mathrm{SN} \text { “líquido” })] \\
& \text { 221. colocar }-\mathrm{VERBO}-\{\text { agente, tema, meta }\}-[\text { [ SN “objeto", SP “lugar”] }
\end{aligned}
$$

Em (220), beber é um verbo, que atribui um papel temático de agente ao que bebe e um papel temático de tema ao SN liquido que é bebido. Em (221), colocar é um verbo, que atribui um papel temático de agente ao que coloca o objeto, um papel temático de tema ao objeto colocado e um papel temático de meta ao local onde o agente coloca o objeto.

O problema dessa proposta é definir exatamente o que é um argumento, quantos ele são e quais são. Além disso, quais são os papéis temáticos existentes e quantos eles são? Não há muito espaço para mudanças e quando um verbo se comporta de modo distinto (como o verbo TER), podendo ser realizado com um ou dois argumentos, temos que supor outra entrada lexical.

A hipótese de proto-roles de Dowty (1991) tenta encontrar uma solução para a lista de papéis temáticos gerada pelo modelo de entradas lexicais. Para este autor há somente dois papeis temáticos: Proto-agente e proto-tema. Cada um deles engloba um 
conjunto de propriedades que devem satisfazer todas as exigências temáticas das línguas naturais.

i. Proto-agente:

- Participa de forma coletiva no evento os estado;

- Capaz de experimentar processos psicológicos e de perceber sensorialmente;

- Causador de um evento ou mudança de estado em outro participante;

- Se move em relação ao outro participante;

- Existe independente do evento que denota o verbo.

ii. Proto-tema

- Sofre uma mudança de estado;

- Tem um tema incremental;

- Se vê afetado de forma causal pelo outro participante;

- Estacionário em relação ao movimento do outro participante;

- Não existe de modo independente do evento que denota o verbo.

A realização de uma expressão lingüística esta governada pelo "Principio de seleção de argumentos", ou seja, em predicados em que haja sujeito e objeto gramatical o argumento com maior número de características de proto-agente se realiza como sujeito, o outro argumento deve ser realizado como objeto.

Entretanto, segundo Mendikoetxea, essa proposta falha por não ser capaz de determinar prioridades ou informar quais são as restrições para a formação de expressões lingüísticas. 
Seria difícil determinar porque em (222) TER tem dois argumentos enquanto em (223) ele é um verbo impessoal:

222. A sala tem três janelas.

223. Na sala tem três janelas.

Por isso, na proposta de decomposição de predicados, a hipótese central é que o inventário de conceitos léxicos, potencialmente infinito, se constrói a partir de uma base inata de conceitos possíveis que deve ser decodificada pelo próprio falante.

A divergência aqui ocorre entre aqueles que crêem que o componente estrutural do significado deve ser definido na forma semântica, modelos semântico-cêntricos, e aqueles que crêem que o componente estrutural do significado deve ser definido na sintaxe, modelos sintático-cêntricos.

Nos modelos semântico-cêntricos, os papéis e as relações temáticas se definem através de uma representação léxico-semântica do significado. Ou seja, são as relações de significado que devem atribuir os papéis temáticos. Já nos modelos sintáticocêntricos, os papéis temáticos se definem de acordo com a posição que ocupam em uma estrutura sintática. Ou seja, um predicador sempre vai atribuir um papel temático para uma determinada posição, o léxico que ocupar essa posição deve ser capaz de recebê-lo.

A segunda grande linha de pesquisa é o modelo (neo)construtivista. De cunho funcionalista, os (neo)construtivistas crêem que o significado do predicador tal como ele aparece na sua entrada lexical não pode ser o que determina a expressão de seus argumentos.

Esse modelo sofreu uma influência do modelo sintático-cêntrico projecionista, pois, assim como eles, adotam uma aproximação configuracional à estrutura sintática, 
ou seja, na configuração de uma expressão lingüística, determinadas posições recebem determinados papéis. Outra influência é a hipótese de interface aspectual de Tenny (1992), na qual os princípios universais do mapeamento entre a estrutura temática e a estrutura argumental são governados por propriedades aspectuais. Ou seja, para a teoria neo-construtivista, as propriedades aspectuais do predicador derivam de forma composicional na sintaxe, os argumentos se projetam livremente na sintaxe e sua interpretação é resultado da interpretação de seus traços aspectuais numa projeção funcional.

Viotti e Pustejovsky adotam uma visão projecionista semântico-centrica. Para eles, o(s) argumento(s) do verbo TER devem receber seu papel temático através das relações entre os significados desses argumentos. Uma vez definida quais são essas relações, TER receberá também o seu significado. Ou seja, como no léxico TER tem uma estrutura qualia sub-especificada, ele só pode se realizar sintática e semanticamente com o significado de posse ou existência, uma vez que algum outro elemento da sentença já foi marcado como núcleo.

Por outro lado, podemos assumir que elementos no contexto conversacional, tais como tópico e foco, também influenciam na escolha do que viria ser marcado como núcleo dessa sentença.

Vejamos desta forma, por questões de economia da língua, é importante que haja apenas uma entrada lexical para o verbo TER. Como no PB esse verbo pode se realizar de duas formas, transitivo ou impessoal, sua estrutura qualia é subespecificada, e as relações de significado vão ocorrer uma vez que um dos complementos da sentença receba a marca de núcleo. Entretanto, a marcação desse núcleo deve ocorrer ainda no léxico. 
Para a teoria (neo)construtivista, as expressões lexicais não deveriam vir definidas do léxico. Elas devem poder ocorrer livremente na sintaxe. Deste modo TER ainda poderia ser sub-especificado, como propõe Viotti, mas o que geraria a interpretação de verbo existencial ou de verbo possessivo seria a própria interpretação dos traços aspectuais da sentença. Ou seja, a composicionalidade de todos os elementos que compõe uma expressão lingüística.

Não quero aqui esgotar uma discussão que tem sido intensa, ambos os lados têm argumentos fortes a seu favor, quero apenas mostrar que o estudo das construções com TER e TENER pode ajudar a resolver alguns pontos, ou pelo menos, levantar outras questões. 


\subsection{A análise de TENER}

Vou passar para a análise das CEs no espanhol. Para tanto verificarei se as propostas de Viotti e Franchi et alii (1998) et alii nos ajudam a entender as diferenças encontradas entre essas duas línguas quando o assunto são as CEs.

Como vimos, ao analisar as $\mathrm{CEs}$ no $\mathrm{PB}$, no caso das sentenças construídas com verbos leves, como TER, fica mais claro entender como o principio de composicionalidade atua. Nos exemplos abaixo vemos claramente que todos os elementos lexicais de uma sentença complexa influenciam na interpretação dessa expressão, inclusive adjuntos, que muitas vezes são considerados opcionais.

224. A Maria tinha muitas jóias.

225. A Maria tinha muitas jóias guardadas debaixo do colchão.

226. A Maria tinha muitas jóias da Regina guardadas debaixo do colchão.

227. A Maria teve muitas jóias destruídas pelo fogo.

Através dos exemplos anteriores vemos que TER não pode restringir sua classificação dentro de um sistema rígido de determinados paradigmas e que, além disso, podemos explicar a multiplicidade de interpretações através da combinação dos sentidos individuais dos itens lexicais.

Será que esta afirmação também é valida para o espanhol? Observemos os exemplos abaixo:

228. María tenía muchas joyas.

229. María tenía muchas joyas guardadas bajo su colchón. 
230. María tenía muchas joyas de Regina guardadas en su casa.

231. María tuvo muchas joyas destruidas por el fuego.

$\mathrm{E}$

232. Mi amiga tenía muchos libros de política y de lingüística.

233. Aquella editora tiene muchos libros de política y de lingüística.

234. Chomsky tiene muchos libros de política y de lingüística.

235. Aquella caja tiene muchos libros de política y de lingüística.

A julgar pelas construções acima, podemos considerar que aquí também todos os itens lexicais das expressões de (228) a (235) interferem na interpretação da sentença. Mais uma vez estamos olhando para o princípio de composicionalidade.

Quando se trata das CEs com TER, sabemos que por ser um verbo leve, TER não tem restrições com seus argumentos (ou se tem elas são poucas):

236. (a) Aquela rua de Chicago tem várias estátuas de artistas famosos.

(b) Tem várias estátuas de artistas famosos naquela rua de Chicago.

237. (a) A festa tinha muita gente.

(b) Tinha muita gente na festa.

Recordemos que, segundo Viotti, o verbo TER não atribui papel temático ao subevento do verbo que está ligado ao argumento, exatamente por ser um verbo leve e esvaziado de conteúdo semântico. A diferença entre as construções em (236) e (237) está em qual dos argumentos recebe a marcação de núcleo, especificando a estrutura 
qualia que estava sub-especificada. Em (236a) e (237a) o primeiro sub-evento está marcado como núcleo (várias estátuas de artistas famosos e muita gente). Por outro lado, em (236b) e (237b), o segundo sub-evento está marcado como núcleo da expressão (naquela rua de Chicago e na festa), gerando CEs.

Por outro lado, o verbo TENER tem restrições e não constrói sentenças existenciais, apesar de construir sentenças apresentacionais e locativas, bem próximas das existenciais:

238. (a) Aquella calle de Chicago tiene varios artistas famosos.

(b) *Tiene varios artistas famosos en aquella calle de Chicago.

239. (a) La fiesta tenía mucha gente.

(b) *Tenía mucha gente en la fiesta.

O interessante é que mesmo sendo um verbo leve, TENER tem mais restrições que TER com relação a seus complementos. Isso pode nos mostrar que TENER ainda tem uma grade sintática argumental plena que deve ser preenchida com dois argumentos, mas que, talvez, não atribua papel temático para seus complementos. Ou seja, sintaticamente TENER está pleno, mas semanticamente está vazio de significado. Dessa forma podemos explicar porque TENER pode construir sentenças que estão distantes de seu significado original de posse.

240. Pedro tiene la nariz demasiado larga. (la nariz de Pedro ERA larga).

241. Tengo la casa patas para arriba. (LLEVO la casa de patas para arriba)

242. Ya tenemos leídos diez libros. (LLEVO diez libros leídos) 
Com relação à estrutura argumental, número e tipos de argumentos que compõem uma expressão com TENER, vamos observar os seguintes exemplos:

243. ?La cama tenía papeles.

244. Era imposible acostarse porque las dos camas tenían aquellos papeles todos del impuesto de renda... ¡El lío era tremendo!

245. Era imposible acostarse porque las dos camas tenían aquellos papeles todos del impuesto de renda desparramados... ¡El lío era tremendo!

Assim como no PB, papeles não predica de cama. Mas ao acrescentar outros itens lexicais no processo de composição a sentença melhora. Quando colocamos outro predicador, desparramados, a sentença fica melhor.

Se acreditarmos que o verbo TENER tem seus argumentos semanticamente subespecificados, temos que explicar porque ele não aceita qualquer item lexical como argumento (locativos, por exemplo).

Como vimos no capítulo anterior, a divisão da estrutura de evento em subestruturas e a relação entre elas pode explicar algumas peculiaridades das CEs do PB.

Segundo Viotti, por ainda manter uma estrutura sintático-argumental de um verbo com dois argumentos (mesmo que ele possa ser realizado com apenas um) TER tem uma estrutura de eventos sub-especificada que apresenta dois sub-eventos, sendo que cada um desses sub-eventos estaria atrelado a um argumento de TER.

Quando estamos estudando o verbo TENER devemos nos questionar se a estrutura de evento de TENER é a mesma de TER. Se for a mesma, tanto TER como TENER devem ser sub-especificados sintaticamente e semanticamente. 
A minha argumentação é que TENER, apesar de poder ser considerado como um verbo leve, assim como TER, não é sub-especificado sintaticamente, pois necessita que sua estrutura sintático-argumental seja preenchida. Isso explicaria porque ainda que seja um verbo leve, faz uma seleção mais restrita que TER. Observemos mais uma vez os exemplos a seguir:

246. María tiene tres gatos negros.

247. Juan tiene un paquete que es de mi hermano.

248. Piedro tiene la nariz demasiado larga.

249. Tengo la casa patas para arriba.

250. Ya tenemos leídos diez libros.

Nos exemplos acima TENER tem o valor de posse (246), de posse transitória (247), pode ser também equivalente a SER (247) ou ainda ter o mesmo valor de LLEVAR (249) e (250). Em todos os casos acima temos sempre a presença de dois argumentos, a ausência de qualquer um desses argumentos geraria uma sentença agramatical, por isso creio que os argumentos de TENER não são sub-especificados sintaticamente como são os argumentos de TER.

Outro ponto é que, de uma forma ou de outra, todos os sentidos gerados pelas construções com TENER têm um sentido possessivo implícito. Então provavelmente não haja porque postular eventos sub-especificados ligados a cada argumento.

Como vimos no capítulo 4.4, no PB é importante que os eventos sejam dois e subespecificados para que haja diferença entre a interpretação possessiva e a existencial em sentenças muito parecidas em seu significado no contexto: 
251. Aquela editora tem muitos livros de política e de lingüística. (1 ${ }^{\circ}$. subevento marcado como núcleo)

252. Tem muitos livros de política e de lingüística naquela editora. (2 $2^{\circ}$ subevento marcado como núcleo)

Mas no espanhol não há porque marcar essa diferença. As CEs no espanhol não se realizam com o verbo TENER:

253. Aquella editora tiene muchos libros de política y de lingüística. ( $1^{\circ}$. Subevento marcado como núcleo)

254. *Tiene muchos libros de política y de lingüísticas en aquella editora. $\left(2^{\circ}\right.$. Sub-evento marcado como núcleo)

Então, não há porque postular uma sub-especificação sintático argumental para TENER. Nesse caso, a análise mais eficiente seria a de Franchi et alii (1998), devemos ver TENER como um operador funcional que, apesar de não atribuir papel temático para seus argumentos por ser vazio de significado, tem a grade sintático-argumental plena, necessitando ser preenchida por um argumento, atribuindo caso a seus argumentos.

Franchi et alii (1998) apresenta algumas argumentações para propor a atribuição de caso acusativo para o argumento único do PB, uma delas é muito interessante para argumentar em favor da atribuição de caso por TENER:

III. A dematização da posição de argumento esterno não exclui outras estratégias de indeterminação do sujeito. Com relação ao esvaziamento da posição de sujeito, 
isso se faz mediante outro mecanismo sintático: a presença de um sujeito indeterminado - como você, ou a gente - em contextos bem claros que excluem uma interpretação predicativa.

No espanhol, podemos ter uma construção parecida com a do $\mathrm{PB}$, e esse exemplo é ainda mais interessante porque se retirarmos o argumento que recebe o caso nominativo, tenho que supor que exista um sujeito oculto, não há como haver uma interpretação impessoal:

255. Cuando surguió esta nueva ley, uno tenia muchas dudas de cómo las cosas relamente ocurririan.

256. Cuando surguió esta nueva ley, tenia muchas dudas de cómo las cosas relamente ocurririan.

Para encerrar essa seção, vou fazer uma breve análise do verbo HABER:

257. Hay muchos livros de política y de lingüística en aquella editora.

No exemplo (257), HABER é um verbo completamente esvaziado de significado, somente atribuindo a sentença o tempo e o aspecto, tal como sugere Franchi et alii (1998) para as CEs com TER.

Lembremos que, para Franchi et alii (1998), o verbo TER é um operador funcional, portador de dêixis temporal e aspectual. A predicação na verdade é estabelecida entre a relação dos constituintes da coda (argumento e predicado secundário).

O mesmo ocorre com HABER no espanhol: 
258. [Hay] [[un gato negro] [cerca de la casa]].

Verbo: operador de tempo e aspecto da sentença apresentada (coda).

Coda: há uma relação de predicação entre seus constituintes

Função: apresentacional, introduz novas entidades no universo do discurso.

No exemplo (258), o verbo HABER é o operador funcional, ele é encarregado de indicar o tempo e o aspecto da sentença, mas na verdade ele não atribui papel temático. A relação de predicação realmente ocorre entre un gato negro e cerca de la casa.

Resumindo, a estrutura do verbo HABER passou por um processo de dematização ou impessoalização. Então, assim como tratamos TER como impessoal em CEs, HABER também deve ser tratado da mesma forma.

Outro ponto é a questão de caso. Mas afinal que caso recebe o único argumento das CEs com HABER? O único argumento da sentença recebe o mesmo caso que TER: caso acusativo:

259. No creo en brujas, pero que las hay, las hay.

Em (259), o pronome las retoma o único argumento do verbo HABER, mostrando que o caso que este argumento recebe é o acusativo. 


\subsection{Uma proposta de análise para os verbos do espanhol arcaico}

O espanhol e o português arcaicos tem muitos pontos em comum. Creio que a única diferença está no não esvaziamento total de $\mathrm{ABER}^{50}$. Diferente de $\mathrm{AVER}, \mathrm{ABER}$ se esvaziou somente de seu significado possessivo. Desta forma, ele parece ter barrado TENER nas formas de auxiliar e de existencial.

Como no português arcaico, o verbo ABER vai se esvaziando de significado e assumindo a posição de verbo auxiliar. Ainda que algumas vezes encontremos, no mesmo período, ABER sendo usado das duas formas:

260. La avemos veída e be[e]ne percebida.

261. Tal batalla avemos arrancado.51

A partir daí é interessante pensar em ABER como sendo sub-especificado, ou seja, se há concordância no particípio então ABER será interpretado como verbo possessivo. Se o particípio não apresentar marca de número ou pessoa ABER será interpretado como um verbo auxiliar.

Assim como no português arcaico, o ABER 'possessivo', o ABER 'auxiliar' e o ABER 'existencial/impessoal' coexistiam, o único modo de diferenciar o primeiro do último era através das marcas de pessoa e de número. Se ABER não mostrava nenhuma concordância com seu objeto então ele deve ser impessoal.

$\mathrm{Na}$ verdade, a única diferença entre o processo de gramaticalização de TENER/HABER e TER/HAVER é que HABER não se esvaziou completamente.

\footnotetext{
${ }^{50}$ Para diferenciar as formas arcaicas de HAVER no espanhol e no português, vou grafar ABER para espanhol arcaico e AVER para português arcaico.

${ }^{51}$ Exemplos 112 e 60 - LAPESA, Rafael (1981), pág. 212.
} 
Outro ponto que deve ser levado em consideração é que HABER como possessivo parece ter demorado mais para se esvaziar, mantendo assim, sua função de auxiliar e de verbo existencial. Podemos ver isso em textos do espanhol arcaico nos quais os autores queriam aparentemente retratar a fala coloquial, como no texto de "La Celestina", que data do fim do século XV e começo do século XVI. Assim, HABER poderia de alguma forma ter impedido o avanço de TENER. Os exemplos a seguir são, com exceção do primeiro que é do século XV, de "La Celestina". Aqui podemos ver que HABER mantinha o significado de posse bem marcado:

262. Elisabel... por su merecimiento huvo hijo santificado antes que naciese (“Cárcel”) 52 .

263. Las paredes han oydos.

264. Dexame tú a Pármeno, que yo te le haré uno de nos, e de lo que hovieramos, demosle parte: que los bienes, si no son comunicados, no son bienes.

265. En lo vegetativo algunas plantas han este respeto

266. Tu madre, que Dios la aya.

267. ¡O si me viesses, hermano, como estás, plazer havrías!

No português arcaico do século XVI, a freqüência de HABER como possessivo era bem restrita (segundo dados de Viotti, HAVER era usado em somente 14,14\% nas ocorrências de posse), enquanto que, aparentemente, durante o final do século XV e

\footnotetext{
${ }^{52}$ Exemplo retirado de ROMANI, P. (2006)
} 
começo do século XVI, HABER possessivo ainda era usado no espanhol arcaico ${ }^{53}$. Então parece que poderia ter havido um esvaziamento tardio de HABER.

${ }^{53}$ Entretanto para se ter maior clareza desse ponto seria necessário um estudo mais aprofundado do uso de HABER e TENER na "Celestina", pois os dados de Hernández Diaz (2006) mostram que o uso de HABER possessivo se resumia a $13 \%$ dos casos no século XVI. 


\subsection{Conclusões}

Se para analisar as estruturas do PB tínhamos duas propostas que pareciam atender de forma satisfatória os dados encontrados, parece que para o espanhol a proposta de ter uma grade argumental sub-especificada não se aplica.

A proposta de Franchi et alii (1998) para as orações com TER parece explicar melhor o tipo de relação que HABER e TENER estabelecem com seus argumentos. Para ele, o sentido de um item lexical deve ser determinado através da relação dos sentidos de todos os itens que compõem aquela expressão lingüística.

Franchi et alii (1998) vêem TER como um operador funcional, um verbo leve, da mesma forma devemos analisar HABER. O verbo deve, nesse caso, simplesmente indicar uma relação entre os outros elementos da coda, expressando o tempo e o aspecto da sentença, mas não atribuindo qualquer papel sintático ou semântico aos elementos da coda.

Com relação à TENER, vemos que ele é um elemento funcional na medida que também não atribui papel temático a seus argumentos, mas ao contrário de TER, sua estrutura argumental não está vazia. Dessa forma, ele precisa atribuir caso nominativo e caso acusativo para seus argumentos. Explicando assim porque as CEs com verbo TENER são agramaticais no espanhol.

Em seguida, tentei demonstrar um pouco da diferença da evolução de TENER e TER tendo em vista a breve análise de um texto muito famoso da literatura espanhola: "La Celestina". E assim, sugerir um caminho de explicação para o não esvaziamento de TENER, que deveria ser aprofundado com um estudo de um corpus amplo. 
CAPÍTULO 6 


\section{Reflexões finais}

Ao longo deste trabalho, tentei mostrar como que são tratadas as CEs tanto no português como no espanhol. Primeiro comecei retratando o que dizem os manuais de gramática de cada língua a respeito de cada um desses verbos (TER, HAVER, TENER e HABER).

Depois apresentei uma breve discussão histórica sobre a evolução do comportamento desses verbos desde o português e o espanhol arcaicos até os dias de hoje.

Tentei argumentar que o motivo pelo qual há essa diferença está no esvaziamento de HAVER e HABER. No português, HAVER se esvaziou primeiro de seu significado de posse e depois passou a concorrer com TER no uso como auxiliar e como verbo impessoal. Sendo que hoje os falantes do PB preferem usar este verbo à HAVER.

No espanhol arcaico, HABER não se esvaziou tanto quanto HAVER. Ele também perde seu significado possessivo, mas não permite que TENER entre nas construções com verbo auxiliar e nem nas construções como verbo impessoal, mostrando que ele não prosseguiu no processo de gramaticalização.

Uma vez que HABER não se esvaziou completamente, TENER também não prosseguiu ampliando sua grade temática, o que explica porque no espanhol não podemos realizar TENER como um verbo impessoal, à semelhança de TER no português:

268. A escola tem piscina.

270. Na escola tem piscina.
X 269. La escuela tiene piscina.

$\mathrm{X} \quad$ 271. *En la escula tiene piscina. 
Depois, apresentei a proposta de Franchi et alii (1998) e de Viotti para as CEs no português do Brasil.

Para Franchi et alii (1998) TER é um operador funcional portador de dêixis aspectual e temporal, a verdadeira relação de predicação ocorre entre os elementos da coda da sentença. As CEs com TER passaram por um processo de dematização, permitindo que sejam realizadas com apenas um argumento, seu complemento direto. Além disso, elas também fazem parte do grupo das sentenças impessoais.

Tendo como ponto de partida a teoria do léxico gerativo de Pustejosky - que afirma que o léxico de tipos complexos deve ser sub-especificado, para que haja apenas uma entrada lexical para um léxico que pode assumir diferentes significados e se explique, entre outras coisas, o uso criativo das palavras - Viotti afirma que TER deve ter sua estrutura qualia e sua estrutura eventiva sub-especificada a fim de poder ora se realizar como um verbo possessivo, ora se realizar como um verbo existencial, ora se realizar como um auxiliar.

Viotti também explica que por ser sub-especificado, TER não atribui papel temático a seus complementos e que, como relação ao caso, o único complemento de TER impessoal deve ser um acusativo.

Ainda dentro das mudanças que ocorreram no português, tentei mostrar como aplicaríamos as propostas de Viotti e de Franchi et alii (1998) para os dados do português arcaico mostrando que, no princípio de seu esvaziamento, HAVER também deveria ter sua grade temática sub-especificada.

Por último, passei a análise dos dados do espanhol à luz da proposta de Viotti e de Franchi et alii (1998) para os dados do português. 
A proposta de Viotti para o verbo TER não se aplica para o verbo TENER. Este último não tem sua grade temática sub-especificada, não haveria porque postular uma estrutura eventiva também sub-especificada para TENER.

Como TENER também pode ser considerado um verbo leve, a proposta de Franchi et alii (1998) parece se aplicar melhor: este verbo seria também um operador verbal e a verdadeira relação temática ocorreria entre os outros elementos da sentença.

Aqui devemos fazer uma pequena consideração, como pudermos ver neste trabalho, TENER não deve ser considerado tão leve quanto TER, por isso, proponho que ainda que ele não atribua papel temático, sua estrutura argumental está plena. Ou seja, TENER ainda precisa ter seus espaços argumentais preenchidos. Isso explicaria também porque o espanhol não permite construções como a vista (271) na comparação com as construções (268) a (270), repetidas a seguir como (275), (272) e (274) respectivamente:

272. A escola tem piscina. $\quad \mathrm{X}$ 273. La escuela tiene piscina.

274. Na escola tem piscina. $\mathrm{X} \quad 275 .{ }^{*}$ En la escula tiene piscina.

Outra questão interessante levantada aqui é sobre as teorias, modelos e hipóteses para trabalhar o léxico. A pergunta que deve ser respondida é: onde são gerados os significados lexicais das palavras? No léxico, na sintaxe ou no contexto? Esse trabalho não pretende responder essas perguntas, mas, como disse anteriormente, o estudo sobre as construções com TER e TENER pode levantar questões interessantes.

Minha intuição é que o contexto faz com que ocorram certas mudanças nos itens lexicais, permitindo o uso criativo das palavras e as mudanças nas estruturas argumentais, qualia e eventiva das mesmas. Creio que exista apenas uma entrada lexical 
para cada item, mas que o uso delas dentro de uma determinada estrutura, dentro de um determinado contexto, faz com que ocorra o principio de composicionalidade, permitindo que esses itens lexicais se tornem complexos e sub-especificados. 
Bibliografia 
ALARCOS L., E. Gramática de la lengua española. Madrid: Ed.: Espasa Calpe, 1994.

ALI, M. Said. Gramática histórica da língua portuguesa. $7^{\text {a }}$ ed. Rio de Janeiro: Ed. Melhoramentos, 1971.

BASSETO, Bruno Fregni. Elementos de Filologia Românica. São Paulo: Ed.: Edusp, 2001.

BECHARA, E. Moderna gramática da língua portuguesa. $37^{\mathrm{a}}$ ed. Rio de Janeiro: Ed. Lucerna, 2001.

BELLO, A. Gramática de la lengua castellana. v. I. Madrid: Ed. Arco libros, 1988.

CAMPOS, H. "Transitividad e intransitividad" In.: BOSQUE, I.; DEMONTE, V (org).: Gramática descriptiva de la lengua española.. v.II. Madrid: Ed. Espasa, 1999. cap. 24, p. 1561-1778.

CANO AGUILAR, R. "El castellano medieval: Morfosintaxis histórica”. In:

El Español a través de los tiempos. $5^{\text {a }}$ ed. Madrid: Ed.Arco libros, 2002.

CUNHA, C.; CINTRA, L. F. L. Nova gramática do Português contemporâneo. São Paulo: ed. Nova Fronteira, 1985.

DEMONTE, V.; MASUllO, P. J. "La Predicación: los complementos predicativos”. In.: BOSQUE, I., DEMONTE, V (org).: Gramática descriptiva de la lengua española.. v.II. Madrid: Ed. Espasa, 1999.

DUARTE, Maria E. L. "Do pronome nulo ao pronome pleno: a trajetória do sujeito no português do Brasil” In.: ROBERT; I. KATO, M (org). Português Brasileiro: uma viagem diacrônica. Campinas: Ed. da Universidade estadual de Campinas, 1993. 
FERNANDEZ S., O.; TABOAS B., S. “Construcciones impersonales no reflejas”. In.: BOSQUE, I., DEMONTE, V (org):: Gramática descriptiva de la lengua española.. v.II. Madrid: Ed. Espasa, 1999.

FRANCHI ET ALII (1998), C.; NEGRÃO, E. V.; VIOTTI, E. “A gramática das orações impessoais com TER/HAVER”. In.: D.E.L.T.A.. v. 14, no. Especial, p.105131. São Paulo, 1998.

GALVES, C. "A sintaxe do português brasileiro". In.: Cadernos de lingüística e Teoria da literatura - ensaios de lingüística, v. 7, no. 13. Belo Horizonte: Faculdade de Letras da UFMG, 1987.

GILI y GAYA, S. Curso superior de sintaxe espanhola. $8^{\text {a }}$ edição. Barcelona: Ed. Spes, 1961.

HANSSEN, F. Gramática histórica de la lengua castellana. $1^{\mathrm{a}}$ edição. Buenos Aires: El Ateneo, 1945.

HERNANDEZ DIAZ, Axel. "Posesión y existencia: la competencia de haber y tener y haber existencial". In.: COMPANY, C.C. Sintaxis histórica de la lengua española: primera parte: la frase verbal. V.1. México: Fondo de Cultura Económica, 2006.

HOPPER, P.; THOMPSON, S. "Transitivity in grammar and discourse". In.: Language. v.26, no.2.

LAPESA, Rafael. História de la lengua española. $9^{\text {a }}$ ed. Madrid: Biblioteca Románica Hispánica, editirial Gredos, 1981.

LEMA, J., RIVERO, M. L. "Types of verbal movement in old spanish: modals, futures and perfects”. In. Probus. v 3, no.3, p. 237-278. Berlin, 1991.

LEONETTI, M. “El artículo”. In.: BOSQUE, I.; DEMONTE, V (org).: Gramática descriptiva de la lengua española.. v.I. Madrid: Ed. Espasa, 1999. Cap. 12, p. 787- 
890.

LIGHTFOOT, D. "Syntactic change". In.: NEWMEYER, F. J. Linguistics: The Cambridge survey - Linguistic theory: foundations. v.I Cambridge: Cambridge University Press. New York, 1988.

MENDIKOETXEA, A. "Construcciones inacusativas y pasivas". In.: BOSQUE, I.; DEMONTE, V.(org): Gramática descriptiva de la lengua española.. V.II. Madrid: Ed. Espasa, 1999. Cap. 25, p. 1575-1630.

MENDIKOETXEA, A. "En busca de los primitivos léxicos y su realización sintáctica: del léxico a la sintaxis y viceversa". In.: $2^{\mathbf{a}}$ Xarxa Temàtica de Gramàtica Teórica. Barcelona, 2004.

MENÉNDEZ PIDAL, R. Cantar de mio Cid: texto, gramatica e vocabulario. v. 1. Madrid: Espalsa-Calpe, 1944.

MENÉNDEZ PIDAL, R. Orígenes del español. Madrid: Espalsa-Calpe, 1950.

MENÉNDEZ PIDAL, R. Documentos lingüísticos de España. Madrid: Ed. Revista Filologica de España, 1966.

MENÉNDEZ PIDAL, R. (1968) Manual de gramática histórica española. Madrid: Espalsa-Calpe.

MIGUEL, E. de. "El aspecto léxico". In.: BOSQUE, I.; DEMONTE, V (org). Gramática descriptiva de la lengua española.. v.II. Madrid: Ed. Espasa, 1999. Cap. 46, p. 2977-3060.

MIGUEL, E. de "Qué significan aspectualmente algunos verbos y qué pueden llegar a significar”. In.: CIPUNTES, J.L.; MARINCÓN, C. (org). Estudios de lingüística: el verbo. Universidad de Alicante, 2004. p. 167-206.

MILANI, E. M. Gramática de Espanhol para brasileiros. $2^{\text {a }}$ edição. São Paulo: Ed. Saraiva, 2000. 
MIRA MATEUS, M. H. et alli. Gramática da língua portuguesa. Coimbra: Ed. Livraria Almeidina, 1983.

NETTO, Maria. do S. S. S. "Ser/estar em 1500”. In.: Estudos Lingüísticos e literários. Salvador: Universidade Federal da Bahia, 1992.

PICALlO, M. C., RIGAU, G. "El posesivo y las relaciones posesivas". In.: BOSQUE, I.; DEMONTE, V (org).: Gramática descriptiva de la lengua española.. v.I. Madrid: Ed. Espasa, 1999. Cap. 15, p. 973-1024.

PIERA, C., VARELA, S. "Relaciones entre morfología y sintaxis". In.: BOSQUE, I.; DEMONTE, V (org).: Gramática descriptiva de la lengua española.. V.III. Madrid: Ed. Espasa, 1999. Cap. 67, p. 4367-4422.

POUNTAIN, C. J. "Copulas, verbs of possession and auxiliares in old spanish: the evidence for structurally interdependent changes". In.: BHS, LXII, 1985.

PUSTEJOVSKY, J. "The semantics of lexical underspecification". In.: Folia Linguistica, 1998. Disponível em:

http://www.cs.brandeis.edu/ jamesp/articles/folia-linguistica-1998.pdf . Acesso em: 26 nov 2007.

REAL ACADEMIA ESPAÑOLA. Esbozo de una nueva gramática de la lengua española. Madrid: Ed. Espasa-Calpe, 1973.

REVENGA T., P. D. "Lengua y notarios en la Castilla del siglo XIII” In. Anuario de estudios filológicos XVII. Universidad de Extremadura, 1995. ROJAS, Fernando. La celestina. V. I. Madrid: Ed. La Lectura, 1913. ROJAS, Fernando. La celestina. V. II. Madrid: Ed. La Lectura, 1913. ROMANI, Patrizia. "Tiempos de formación romance I. Los tiempos compuestos". In.: COMPANY, C.C. Sintaxis histórica de la lengua española. Primeira parte: la frase verbal.. V I. México: Fondo de cultura económica, 2006. 
SAMPAIO, M. L. P. Estudo diacrônico dos verbos TER e HAVER, duas formas em concorrência, 1978.

SILVA, R. V. Mattos e. "Um aspecto auxiliar no português arcaico.” In.: Tulane studies in romance languages and literature. no. 10, 1981.

SILVA, R. V. Mattos e. "Caminhos de mudanças sintático-semânticas no português arcaico.” In.: Cadernos de Estudos Lingüísticos. no. 20, p 59-74. Campinas, 1991. SILVA, R. V. Mattos e. Estruturas trecentistas: elementos para uma gramática do português arcaico. Lisboa: Imprensa Nacional - Casa da Moeda, 1989.

SILVA, R.V. M. e. “A variação 'haver'/‘ter'”. in.: (org) A carta de caminha: testemunho lingüístico de 1500. Salvador: Edufba, 1996. p. 183-193.

SILVA, Rosa Virgínia M e. O Português arcaico: morfologia e sintaxe. São Paulo: Ed. Contexto, 1994.

SILVA, Rosa Virginia Mattos. A mais antiga versão portuguesa dos quatro livros dos diálogos de São Gregório v. I. Tese (doutorado em letras) - Faculdade de Filosofia, Letras e Ciências Humanas, Universidade de São Paulo. São Paulo, 1971. SILVA, Rosa Virginia Mattos. A mais antiga versão portuguesa dos quatro livros dos diálogos de São Gregório. v. II. Tese (doutorado em letras) - Faculdade de Filosofia, Letras e Ciências Humanas, Universidade de São Paulo. São Paulo, 1971. VAANANEN, V. Introducción al latín vulgar. Madrid: Ed. Gredos, 1985. VIOTTI, Evani. "O caso do sintagma nominal das sentenças existenciais". In.: Fórum Lingüístico. v.2 no. 1. UFSC, Florianópolis. 2000.

VIOTTI, Evani. "A predicação e as relações temáticas nas sentenças com verbo TER- parte II’. In:. Seminários em teoria gramatical. no.16, FFLCH - USP. São Paulo, 1998.

VIOTTI, Evani. A sintaxe das sentenças existenciais do português do Brasil. 
Tese (doutorado em letras) - Faculdade de Filosofia, Letras e Ciências Humanas, Universidade de São Paulo. São Paulo, 1999.

VIOTTI, Evani. “A composicionalidade nas sentenças com o verbo 'ter'. In.: Muller, A.L.P.; Negrão, E.V.; Foltran, M.J. (orgs) Semântica formal. São Paulo: ed. Contexto. 2003.

VIOTTI, Evani. “Uma historia sobre 'ter' e 'haver””. In.: a sair em Cadernos de Estudos Linguisticos. São Paulo. 